Kelvin W. Willoughby

\title{
INTELLECTUAL PROPERTY MANAGEMENT AND TECHNOLOGICAL ENTREPRENEURSHIP
}

\author{
Published in: \\ International Journal of Innovation and Technology Management \\ Vol. 10, No. 6 (2013) 1340027 (42 pages) \\ (C) World Scientific Publishing Company. \\ DOI: $10.1142 / \mathrm{S} 0219877013400270$
}

This is a pre-publication draft only.

For access to the final published version please go to the publisher's web site at: http://www.worldscientific.com/worldscinet/ijitm 


\author{
International Journal of Innovation and Technology Management \\ Vol. 10, No. 6 (2013) 1340027 (42 pages) \\ (C) World Scientific Publishing Company. DOI: 10.1142/S0219877013400270
}

PRE-PUBLICATION DRAFT

\title{
INTELLECTUAL PROPERTY MANAGEMENT \\ AND TECHNOLOGICAL ENTREPRENEURSHIP
}

\author{
KELVIN W. WILLOUGHBY \\ Professor of Entrepreneurship and Intellectual Property \\ School of Electrical Engineering and Computing, Faculty of Science and Engineering \\ Curtin University, GPO Box U1987, Perth WA 6845, Australia \\ k.willoughby@curtin.edu.au \\ www.DrKelvinWilloughby.com
}

Received (9 September 2010)

Revised (20 October 2011)

Accepted (9 April 2012)

\begin{abstract}
This paper investigates the distinctive technology protection strategies of entrepreneurial technology firms. In contrast with much popular opinion, it is reported that intellectual property features more prominently in the business of small entrepreneurial firms than it does in the business of large, established mature firms. The intellectual property portfolios of technology firms of all sizes and ages exhibit a rich array of instruments in addition to patents for protecting technology, including trade secrets, trademarks and copyright, together with licenses to externally sourced technology. The intellectual property profiles of technology firms appear to be influenced by their context, organizational profiles and corporate goals and by the character of their technology.
\end{abstract}

Keywords: Intellectual property, entrepreneurship, trade secrets, patents, copyright, trademarks, licensing, bioscience, SMEs, IP profiles.

\section{Introduction: Knowledge, Learning, Intellectual Capital and Intellectual Property}

The emergence of the knowledge based view of the firm during the last two decades within the academic literatures of management, organization and economics has reflected the increasing prominence of knowledge as a key source of wealth creation in society and a key source of competitive advantage for firms and regions [Nonaka (1994); Nonaka \& Takeuchi (1995); Sveiby (1997); Stewart (1999); Jin (2001); Willoughby (2004); Curado $\&$ Bontis (2006)]. This has led to a steady stream of research on the theme of intellectual capital and the related theme of intellectual assets as either complements or substitutes for orthodox categories of capital, such as financial capital, physical capital and human capital [Edvinsson (1997, 2000); Booker et al. (2008); Tan et al. (2008)]. These trends in academic research have stimulated a concomitant interest in the challenges of both managing [Quinn (1992); Bontis (1999); Teece (2000)] and measuring [Curado \& Bontis (2007)] intellectual capital. 


\section{$2 \quad$ K. W. Willoughby}

Under the general conceptual umbrella of managing intellectual capital, a number of focus areas of academic inquiry have emerged. One of the most important of these focus areas is the role of learning and knowledge transfer in organizations, particularly as it pertains to problem solving and product development in competitive technology intensive settings. The issue of learning through knowledge transfer has been addressed as both an intra-firm issue [Nonaka (1994)] and an inter-firm issue [von Hippel (1988, 1994, 1998); Weber $(2002,2003)]$. Thus, finding ways to manage intellectual capital so that the "stickiness" of knowledge is reduced in order that it may be transferred more quickly and efficiently for the purpose of learning has become a central concern of researchers operating within the framework of the knowledge based view of the firm.

The transfer of knowledge between organizations evokes special challenges when proprietary rights are involved. When knowledge is "owned"-when exclusive rights are attached to knowledge (as is the case with patents, copyright, trade secrets or design rights, for example) - the process of transferring knowledge may, according to some commentators, be slowed down severely or even blocked [Jaffe \& Lerner (2004); Bessen \& Meurier (2008); Boldrin and Levine (2008)]. Some of the legal requirements for gaining intellectual property rights (e.g., employee confidentiality agreements, under trade secret law, or prohibitions on publicly sharing information about inventions prior to filing patent applications) may also even constrain the internal operations of firms. Thus, questions about the characteristics of intellectual property and the management of intellectual property arise naturally from research about knowledge, learning and intellectual capital [see, e.g.: Williamson et al. (2003); Craig \& Moore (2011); Dolfsma (2011)]. This paper seeks to contribute to the ongoing debate about this topic by exploring the role of intellectual property in the business of entrepreneurial technology firms, through both a survey of the pertinent literature and through reporting the results of an original empirical study on the subject. It explores the degree to which entrepreneurial technology firms engage in the management of intellectual property, the character of that engagement and the extent to which the intellectual property profile of entrepreneurial technology firms differs from that of large established technology firms.

The paper investigates what are the typical mixes of intellectual property instruments that are selected by managers of entrepreneurial technology firms to protect their firm's technology. To this end, variations in the intellectual property portfolios of firms are identified and analyzed over a variety of business dimensions; and contrasts between the profiles of entrepreneurial firms and the profiles of large mature corporations are examined. Original data collected directly from the managers of bioscience-technology firms in the United States - chosen, among other reasons, because of their premier status as representatives of the "high technology" sector-form the basis of the analysis.

As reported in the following pages, the research results reveal that such "high technology" firms, across both the size spectrum and the age spectrum, typically follow a variegated intellectual property portfolio management approach rather than a conventional patent administration approach to protect their technology. In addition to patents, the intellectual property portfolios of these firms contain a rich array of instruments for protecting their technology, including trade secrets, trademarks and copyright, together with licenses to externally sourced technology. The results also provide evidence that intellectual property management plays a prominent role in the 
business of entrepreneurial technology firms. In fact, it appears from the results reported in this paper that intellectual property plays a more prominent role in the business of small, entrepreneurial technology firms than it does in the business of large, established mature technology firms.

It is suggested that the development of an intellectual property strategy for a technology firm is heavily influenced by the firm's context, its organizational profile, its corporate goals and the character of its technology; and that this general principle applies to small and young firms at least as much as it applies to large and established firms. Thus, the challenges of developing and implementing an intellectual property strategyfor small and young firms as well as large and established firms - mirror those of developing an overall business strategy or corporate strategy, in terms of both the complexity of the challenges and the contingencies that may come in to play.

Why is this an interesting conclusion? As will be discussed in the body of the paper, a number of commentators and observers believe that the benefits of intellectual property accrue disproportionately to large established firms and that the costs (both direct costs and transaction costs) of obtaining intellectual property rights, and of appropriating business value from them, work against the interests of small and medium sized enterprises. The fact (at least as reported in this paper) that small and medium sized enterprises typically invest proportionally more heavily in intellectual property than do large established firms, suggests that some popular beliefs about this subject are misplaced. The distinctive intellectual property profiles of entrepreneurial technology firms, in contrast with those of the large established firms, may provide clues as to how entrepreneurial managers go about crafting strategies to match their difficult circumstances.

\section{Literature Review: Context}

\subsection{The role of intellectual property in technology-intensive business}

Intellectual property has become a prominent theme in academic research, policy analysis and policy debates concerning the role of technology in national and international economic development [Subramanian (1991); Lehman (1996); Lai (1998); Braga et al. (2000); Maskus (2000); Scherer \& Harhoff (2000); Shultz \& Nill (2002); Granstrand (2003); Chen \& Puttitanum (2005); Grossman \& Lai (2005); Kiskis \& Petrauskas (2005); Branstetter et al. (2006); Mondal \& Gupta (2006); Scotchmer (2006)]. In parallel with that trend, scholars and observers of business and strategy have increasingly directed attention to the importance of intellectual property within the overall strategic management of enterprises [Goto, et al. (2002); Fitzpatrick \& DeLullo (2005); Parchomovsky \& Wagner (2005); Walden 2005; Elmslie \& Portman 2006; Kahn 2007; Peeters \& van Pottelsberghe de la Potterie 2006; Siegel \& Shah (2006); Giuri et al. (2007); Rose et al. (2007); Blind et al. (2009); Solitander \& Solitander (2010)], with some [e.g., Pisano \& Teece (2007)] even recognizing that firms may sometimes consciously seek to influence the intellectual property regime under which they operate as a means of building competitive advantage.

Thus, intellectual property has become a new leitmotif of both economic research and research in to the strategic management of business enterprises. In keeping with this 
development the subject matter of intellectual property is no longer seen as the special preserve of the legal profession: intellectual property management now stands alongside intellectual property law as an essential complementary modality for the development and maintenance of intangible assets [Granstrand (2000); Bosworth \& Webster (2006); Jolly \& Philpott (2009); Kaiser (2010)].

\subsection{The usefulness of intellectual property to small and medium sized enterprises}

A sub-theme of this broad intellectual development, within both economics research and business research, concerns the special relevance of intellectual property to the business of entrepreneurial technology firms and to small and medium sized enterprises (SMEs) more generally [Kitching \& Blackburn (1999); Tietze et al. (2006); Greenhalgh \& Rogers (2007); Blind et al. (2009); Häussler et al. (2009); Lichtenthaler (2009)]. Much of this special literature seeks to address the question of whether or not SMEs in the technology sector have more to gain from intellectual property rights than larger or more mature technology firms, or whether, regardless of whether or not in principle they have more to gain, SMEs are in fact disadvantaged vis-à-vis their larger counterparts when it comes to obtaining intellectual property protection for their technology, enforcing their intellectual property rights or extracting value from those rights.

While this field of inquiry appears to be a lively and growing domain for research, a consensus has not yet appeared in the literature in answer to the foregoing question. Much of the investigation and debate relates to the relative impact of variables such as technology intensity, industry membership, geographical and legal context, and the morphology of firm age or size compared with firm-specific variables such as the peculiar management attributes and strategy of individual enterprises. The question of just how the approach of small or young technology enterprises to the management of intellectual property therefore ought to differ, if at all, from that of large or mature technology enterprises, still remains open.

This paper contributes to the conversation around this sub-theme within business research related to intellectual property by seeking to identify the variety of strategies between which entrepreneurial technology firms (the vast majority of which tend to be young SMEs) may choose when seeking to protect their technology. Rather than answering the general question of whether or not the benefits of intellectual property rights accrue unevenly between small and large firms, this paper articulates the range of protection mechanisms available to entrepreneurial technology firms, the variety of ways in which they may be mixed, and the forces that may determine the particular intellectual property solution adopted by each firm. In particular, this paper seeks to identify whether there is an obvious "best practice" generic intellectual strategy for entrepreneurial technology firms or whether, if there is a choice between a diversity of strategies, what forces might constrain how an enlightened manager might go about making that choice. Contrasts between the behaviors of small or young firms and large or mature firms are examined in this paper in an attempt to elucidate what distinctive challenges may be faced by the managers of entrepreneurial technology companies for the management of their intellectual property. 


\subsection{Contemporary approaches to intellectual property management}

In contrast with the conventional view of intellectual property management for technology firms - which tends to focus on patents, patent law and patent administration - a number of commentators have recognized that a variety of legal devices, methods and rights are available for the protection of a firm's technology and that these protection vehicles need to be managed in the manner of a portfolio of assets and rights [Cohen et al. (2000); Greenhalge \& Rogers (2007); Blind, et al. (2009)]. Typologies of stages of "advanced" approaches to intellectual property management have begun to appear in the literature, bringing intellectual property management to the edge of the mainstream in strategic management discourse. The following observation by three European scholars representative of this new approach is illustrative [Tietze et al. (2006): 520]:

IP management systems are becoming increasingly complex and strategic in handling an integrated portfolio of IPRs ${ }^{*}$ and intellectual assets rather than just "administering" patents, trademarks and copyrights as single, independent assets in an operational management way.

With this perspective in mind, the literature now points to the fact that a wide variety of behaviors may be identified between firms in the way that they manage intellectual property [Erkal (2004); Greenhalge \& Rogers (2006); Giuri et al. (2007); Hanel (2008)]. Thus, sophisticated approaches to intellectual property management require recognizing both the variety of legal and other vehicles available for protecting a firm's technology and the variety of ways that individual firms might go about configuring a selection of such vehicles to match their own unique circumstances.

How should a manager of an entrepreneurial firm choose an appropriate protection strategy for the firm's technology? What criteria should guide that choice? The answers to these two questions will need to be left to a subsequent research. However, in this paper it will be possible to investigate what forces appear to drive and constrain the decision making process of managers when it comes to intellectual property strategy? Insight based upon analysis of such forces may suggest a way forward for future research in to normative principles for intellectual property strategy for entrepreneurial technology firms.

\subsection{Technological characteristics and intellectual property}

The current literature provides some clues about what we might discover through empirical research. Some researchers, for example, have argued that the level of a firm's technology - in other words, the degree to which it is "high tech" — will drive the choice of protection strategy [Hanel (2008); Lichtenthaler (2009)]; although this point of view is not supported by the results of all published research on the topic [Arundel (2001)]. One study has produced evidence that firms in "high tech" industries are faced with higher levels of competition than firms in "low tech" industries due to their need to constantly renew both their R\&D efforts and their intellectual property protection portfolios [Greenhalgh and Longland (2005)].

\footnotetext{
"Note: "IPRs" is a widely used abbreviation for "intellectual property rights" and "IP" is a widely used abbreviation for "intellectual property."
} 
The scale of the technological advance of an invention [Anton \& Yao (2004)] or the level of inventive-step or non-obviousness of a technological invention [Erkal (2004)] have also been raised as determinants of inter-firm variations in intellectual property strategy. It appears that the characteristics of a firm's technology play an important role in the adoption of an intellectual property strategy, but the degree to which this is so, the manner in which it takes place, and the connection between this factor and other factors, is not yet understood.

\subsection{Industry context and intellectual property}

Other researchers [Cohen et al. (2000); Rherrad \& Gallaud (2009)] have pointed to the industry to which a firm belongs, rather than the nature of its technology, as a factor determining its intellectual property profile; and there is some evidence that the impact of industry context has an even greater influence on the adoption of intellectual property strategy by SMEs than it does for other firms [Olander et al. (2009)]. Of course, there is often a close link between the particular industry to which a firm belongs and the characteristics of its technology, but this coupling is usually rather loose and there is often a great deal of variety in the technological profiles of firms within the same industry (for evidence from the biotechnology industry, for example, see Willoughby [1992]). Hence, despite their influence on each other, industry factors and technological factors may be considered here as distinct, albeit intermingled, factors in the development of intellectual property strategy by firms.

\subsection{Firm size and intellectual property}

Nothwithstanding the evidence that has been published suggesting that industry plays a signal role, some empirical research has suggested that other factors, such as the size of the firm, exert greater influence on intellectual property strategy than industry-specific factors [Blind et al. (2006); Jensen \& Webster (2006)]. The size of a firm appears to influence both the choice of protection vehicles for the firm's technology and the strategic purposes behind its decision to obtain such protection. Kitching and Blackburn [1999] have produced evidence that small firms rely upon intellectual property rights to protect their technology to a lesser extent than do large firms. This result has been reproduced independently by others [e.g., Hanel (2006)]. Greenhalge and Rogers [2006] have shown, interestingly, that medium-sized firms may be more intellectual property intensive than large firms.

Thus, while there appears to be a connection between the size of a firm and the intensity of its reliance upon intellectual property, this relationship does not appear to be a simple linear relationship, and it is perhaps moderated by other factors. When the field of technology is complex it appears that SMEs may often obtain less benefit from intellectual property rights than is typically the case for larger firms [Kash \& Kingston (2001)]. The results of research in this field that have been published thus far are therefore not very robust. 


\subsection{Firm value and the value of intellectual property}

A rich body of literature has emerged in recent years concerned with the valuation of intellectual property - especially patents - and also the effect that such valuation has on the value of firms [e.g., Barney (2002); Harhoff et al. (2003); Baudry \& Dumont (2006); Bessen (2008); Lagrost et al. (2010)]. Some of this literature explores differences in the relationship between patent valuation and firm valuation according to the size of the firm. Bessen [2008], for example, has published evidence that patents issued to small (generally young) firms tend to be less valuable than those issued to large established corporations. Part of the explanation for this phenomenon may derive from the fact that the value of a patent tends to increase significantly if it has been successfully litigated [Lanjouw \& Schankerman (2004); Bessen (2008)] and that small young firms are generally less capable of engaging in expensive and time-consuming litigation to protect their patent rights than are large established corporations. On the other hand, there is also evidence in the literature that the positive relationship between patent value and firm value is stronger for small young firms than it is for large established firms [Greenberg (2010)]. While this evidence does not strictly speaking contradict the results of Bessen's work it does reveal that the relationship between patent value, firm value and firm size (or age) needs to be addressed from multiple vantage points.

A related literature has addressed the effect of trading patents on the value of those patents and hence on the value of the firms to which those patents belong [Arora et al. (2001); Serrano (2005, 2010); Figueroa \& Serrano (2010)]. The general conclusion of the literature is that, in general, when a patent is traded (i.e., when the ownership of a patent is transferred from one person or company to another) its financial value increases. The existence of markets for trading intellectual property tends to increase the value of the assets in question. Of particular relevance to this paper, however, is the discovery that there are apparently size-related differences in the propensity of firms to trade intellectual property rights. Serrano's research [2010] has shown that small firms are more likely than large firms to trade patents; and Figueroa and Serrano [2010] have found that the relatively high propensity of small firms to trade patents may be observed in both directions: in other words, small firms are more likely than large firms to both sell patents and buy patents.

\subsection{Tentative conclusions about the context of intellectual property management in firms}

We may conclude tentatively that the size of the firm matters when it comes to intellectual property management; but the literature has not yet yielded unambiguous evidence about either the strength of that relationship or the character of that relationship. Additionally, we may tentatively conclude that the size of the firm matters when it comes to enjoying the benefits, including the financial benefits, of intellectual property. Once again, however, the relative advantages or disadvantages of size vary according to the particular factors under consideration.

The inter-organizational relationships of firms also seem to influence, or at least moderate, their intellectual property strategies, especially when they are R\&D intensive firms. The degree to which firms engage in cooperative R\&D activities with other 
organizations, especially universities, appears to affect both the choice of legal protection vehicles for technology and the frequency of reliance upon intellectual property rights for protection of technology [Leiponen \& Byma (2009)]. The kind of organizations with which a firm interacts and the overall propensity of that firm for interactions with the outside world seem to play at least a moderating role if not a determining role in that firm's intellectual property protection practices.

The existing academic literature in the field of intellectual property management provides substantial evidence that the intellectual property protection profiles and strategies of firms vary considerably; and it provides substantial evidence that there are a variety of forces at work influencing the intellectual property profile of each firm. What, then, can be said about the content of decisions made by the managers of technology firms and the mixture of elements that make up the intellectual property profiles of firms?

\section{Literature review: Themes and Questions for Empirical Research}

\subsection{Diversity in the configuration of intellectual property profiles}

In keeping with the emerging theme identified above of managing a portfolio of intellectual property rights and intellectual assets, rather than engaging simply in the administration of patents, a growing body of research on intellectual property management is directed towards examining the relative merits of alternative forms of protection for technology and of technological know-how more generally. In particular, a number of scholars have produced indicative evidence and forceful arguments in support of trade-secret protection as an alternative to patent protection for technology enterprises [e.g., Horstmann et al. (1985); Durvey (1999); Apke (2003); Graves \& Range (2006); Ann (2007); Ann \& Grüneis (2008); Rowe (2008); Stead \& Cross (2009); Price (2010)]. Despite the fact that trade secret protection has conventionally been portrayed (usually with good reasons) by legal practitioners working in the field of technology business as inferior to patent protection, evidence is mounting that trade secrets remain prominent in the intellectual property portfolios of technology firms [Kitching \& Blackburn (1999); Cohen et al. (2000); Arundel (2001); Hanel (2008)].

\subsection{Trade secret rights and patent rights as alternative protection regimes}

In parallel with the wave of criticism leveled at the patent system during recent years [e.g., Jaffe \& Lerner (2004); Bessen \& Meurer (2008); Boldrin \& Levine (2008)], and the observation by some that the benefits of the patent system are often unattainable for many technology firms [Harabi (1995); Kash \& Kingston (2001); Leiponen \& Byma (2009)] - especially when doing business in parts of the world with weak enforcement regimes [Lu (2007); Keupp et al. (2010)] — a modest body of literature is now appearing in which the possible superiority of trade secret protection over patent protection is being asserted, at least for certain classes of firms and certain situations when carefully assessed [e.g., Olander (2009); Ann (2010); Price (2010)]. Included among the advantages of trade secrets over patents are lower financial costs, no registration requirement, an absence of the need to disclose proprietary information to competitors, and the possibility (in principle) of permanent protection (unlike patents, which typically expire no later than 20 years after an application has been filed). 
A number of studies have been published where patents and trade secrets are essentially treated as alternative options between which managers of technology firms may choose when seeking to protect their intellectual assets [Beckerman-Rodau (2002a); Erkal (2004); Garvey \& Baluch (2007); Ann (2007, 2010)]—as opposed to the conventional attitude wherein trade secrecy might be viewed as an option of last resort if patent protection were, for some reason, not viable. Some authors have adopted this intellectual stance in practice-oriented empirical studies [e.g., Kitching \& Blackburn (1999); Arundel (2001); Hussinger (2006); Leiponen \& Byma (2009)] and others have adopted it as part of formal economic modeling dealing with intellectual property choice [e.g., Horstmann et al. (1985); Anton \& Yao (2004); Kultti (2007); Ottoz \& Cugno (2008)].

Information on the procedures and tactics that firms need to adopt in order to ensure legal enforcement of trade secret rights is becoming more readily available [e.g., Beckerman-Rodau (2002b); Apke (2003); Rowe (2008); Snyder \& Almeling (2008); Price (2010)]. In short, scholarly work in the field of intellectual property management has gone beyond the stage of debating about which of the two forms of intellectual property protection - patents rights or trade secret rights - are theoretically superior, as a matter of principle, to seeking to understand what choices firms actually make in practice, how they make those choices and what forces seem to drive the adoption of one option rather than the other.

What are some of the results that have emerged thus far in academic research about the mix of intellectual property protection vehicles-especially patents and trade secrets - adopted by firms and the rationale for those particular choices?

\subsection{Trade secrets, patents and the preferences of small and medium sized enterprises}

One group of authors has observed through their research that, on the whole, SMEs tend to prefer informal (non-registered) methods, typically involving trade secrets, for protecting their technology rather than formal (registered) methods, typically involving patents [Kitching \& Blackburn (1999); Cohen et al. (2000); Hanel (2008); Leiponen \& Byma (2009); Olander et al. (2009)]; although some [e.g., Arundel (2001)] aver that trade secrets are generally preferred over patents regardless of firm size. It is argued that trade secrets can provide superior protection to patents under certain conditions, such as when the disclosure of technological information as part of the patent system will provide undue leverage to competitors [Horstmann et al. (1985)], when the likelihood of parallel invention or imitation by competitors is low [Kultti et al. (2007)], when the scale of the innovation or the technological advance is large [Anton \& Yao (2004)], when the appropriability regime is weak [Pisano \& Teece (2007); Ann (2010)], when firms are unable to obtain access to the necessary resources to obtain patent rights [Kitching \& Blackburn (1999)], or when firms are developing inventions that require considerable work before they will be ready for commercialization [Hussinger (2006)].

Some commentators [e.g., Arundel (2001)] treat the patent / trade-secret decision as a mutually exclusive choice because the two forms of protection are seen as intrinsically incompatible - since patents require disclosure and trade secrets, by definition, are destroyed by disclosure. Others, however, recognize that a company's technology may 
consist of a variety of complementary technologies, some of which lend themselves to patent protection and some of which lend themselves to trade secret protection [Horstmann et al. (1985); Beckerman-Rodau (2002a); Erkal (2004); Garvey \& Baluch (2007); Kultti etal. 2007; Hanel 2008; Ottoz \& Cugno 2008; Ann et al. (2011)]—and hence that they can either substitute for each other or be mixed as part of an intellectual property package.

Some researchers [Rherrad \& Gallaud (2009)] argue that firms in "high tech" industries are forced to move fast as a consequence of the intense competition they face in their industries and, hence, naturally prefer "secrecy" over patent protection, regardless of the size of the firm. Additionally, Olander et al. [2009] have made the interesting observation that SMEs have a tendency to focus on the protection of "innovative inputs" (which lend themselves to trade secret protection and other complementary managerial practices) in contrast to the protection of "innovative outputs" (which lend themselves to patent protection) and which, so it is believed, are thus more easily managed by larger more resource-rich firms.

\subsection{Questions for empirical research}

The following questions for empirical research are evoked by the ideas, insights, research results and debates found in the literature surveyed above:

- Is there one obvious managerial formula or "best practice" strategy that is adopted by the vast majority of firms for the legal protection of technology and for the management of intellectual property more generally, or are a wide variety of formulae and strategies exhibited by firms?

- Insofar as a wide diversity exists in the managerial formulae and strategies exhibited by firms $v i s-\grave{a}$-vis intellectual property, may any obvious structure or pattern of practices be discerned within that diversity?

- Is the patent right the dominant type of intellectual property right upon which firms rely to protect their technology?

- How prominent are the positions of trade secrets, copyright, trademarks and other forms of intellectual property protection alongside patents in the intellectual property portfolios of firms?

- Are trade secrets (which do not generally require registration) especially preferred by small and medium sized enterprises over other forms of intellectual property, such as patents, that do require registration?

- Does intellectual property occupy a more-prominent or less-prominent position in the business of small, young entrepreneurial technology firms than it does in the business of large, established, mature technology firms?

- Does the typical intellectual property portfolio of small, young entrepreneurial technology firms differ in its profile from the typical intellectual property portfolio of large, established, mature technology firms?

- What are the forces or factors that appear to determine or constrain the intellectual property profile of technology firms? 
The balance of this paper will be devoted to addressing the above questions by reporting the results of original empirical research about the behaviors of technology firms vis-à-vis intellectual property management. The results are drawn from a ground-up study of firms in industries that are preeminent examples of "high technology" industries and that are heavily entrepreneurial in nature - the "bioscience-technology" industries in the United States. The above eight questions may be condensed in to the following triple question at the core of this paper: what practices do firms actually adopt to protect their technology, what special shape do these practices take for entrepreneurial firms, and what forces seem to influence the adoption of one approach rather than other approaches that, in principle, may be available to a firm?

\section{Research Methodology and Data Collection}

\subsection{Choice of industry sample: The bioscience-technology industries of the United States}

All of the empirical data that were collected by the author during this study came from a sample of firms in the bioscience-technology industries in the United States. This industry sector was selected because it is replete with excellent examples of the "high technology" firms about which much of the literature on intellectual property is concerned; yet it is also very diverse in both its technological character and the technological intensity of its firms and products. The sector includes not only dedicated biotechnology firms (narrowly defined) but also firms active in medical devices technology, pharmaceuticals technology, and other fields of technology related to the life-sciences (predominantly bio-processing). This group of firms, including dedicated biotechnology firms, may be labeled collectively as the "bioscience-technology" sector. Additionally, the sector exhibits wide diversity in the morphology of its member firms related to size and age.

The data to be described below were drawn from field-based empirical studies of the bioscience-technology industries in the United States during 1996, 1997 and 1998, from two states, New York and Utah. The geographical and temporal scope of the data collection was chosen partly for pragmatic reasons: because the author was able to obtain invaluable financial and practical support for the research from the pertinent industry and government organizations in those states during the time period in question. However, these two states-New York and Utah — were also chosen for substantive theoretical and policy reasons related to the current author's research about the financial and economic dimensions of the "bio" (or "life sciences") industries. Both states were widely recognized as homes to substantial, and growing, bioscience technology industries; but they were especially interesting because, despite the fact that they each possessed a substantial number of firms in the pertinent fields, they might nevertheless be considered as second-tier bioscience technology regions compared with competitor states such as California and Massachusetts. This feature made them very interesting from the point of view of economic development dynamics and also especially challenging from the point of view of entrepreneurial strategy, including financial strategy, in non-dominant regional geographic industry clusters. 
It was possible to obtain data about the intellectual property profiles of firms because the data (most of which are highly confidential) were collected as part of a wider regional economic study. The types of data that form the heart of this research are simply not available from public sources. In short, it was only possible to collect such high quality and confidential firm-level data about intellectual property by collecting those data alongside other confidential business data being assembled for another research purpose. ${ }^{\dagger}$ While the data were generated in the late 1990s they are still relevant since the industries from which they were derived remain prime examples of key advanced-technology industries of interest to both policy makers and investors. They are also characterized by both high degrees of technological entrepreneurship and heavy reliance upon intellectual property as an integral aspect of business practice.

\subsection{Data collection method}

The data collection method ${ }^{\S}$ in each state involved two main phases. The first phase, which was conducted from July 1996 to December 1996 in New York, and from March 1998 to June 1998 in Utah, consisted of an exhaustive census of all firms in each state active in bioscience technology. To be included in the study a firm had to pass through a number of analytical filters: (i) the firm had to be an identifiable bona fide business in its respective state, with its core operations located within that state; (ii) its dominant activity needed to be centered on at least one of the four sub-fields of bioscience technology defined above; (iii) it needed to possess a significant internal technical capability of its own within bioscience technology; (iv) it needed to either conduct R\&D in bioscience technology, produce bioscience technology, employ bioscience technology as the dominant part of its business, or produce specialized technical supplies for bioscience technology; and, (v) it needed to devote the majority of its efforts to the above activities.

A master list of candidate organizations in bioscience technology was assembled for each state from multiple sources, starting with several thousand in New York and just under a thousand in Utah. Each organization on this list was subjected to two rounds of inquiries: an initial check for information consistency, plausibility and verification as to whether or not the organization was still in business or was actually located in its respective state; and a second inquiry, conducted mostly by telephone, to identify whether the firm could successfully pass through all the analytical filters indicated above (this process reduced the candidate list to about 300 firms, in the case of New York, and about 125 firms, in the case of Utah). An additional (fine-tuned) analysis of all firms which made it through the above two inquiry processes revealed the verifiable industry population in New York State to be 273 bioscience technology firms (by May 1997) and 116 bioscience technology firms in Utah (by July 1998).

\footnotetext{
$\dagger$ For results of the partner study to this study (an investigation of the finances of the biosciencetechnology industries), including a description of the sample selection and data collection process that produced the data for both this study and that study, see Willoughby [2008].

$\$$ For a recent review of the current status and ten-year history of the bioscience-technology industries in eleven U.S. states and the U.S. as a whole, see Willoughby [2011].

${ }^{\S}$ Please note that the data collection method (Section 4.2) and the basic characteristics of firms in the sample (Section 4.3) are identical to the equivalent sections of the published results of the partner study [Willoughby (2008): 8-12].
} 
The second phase consisted primarily of detailed structured questionnaire surveys of the population of firms identified in each census. This work involved three sub-phases: (i) sending introductory letters (from the appropriate industry associations in each state) to every bioscience technology firm in the population identified for each state to introduce the study and its purposes; (ii) completing the first half of the questionnaire through a structured telephone interview with the CEO (or CEO-equivalent) of each firm; and, (iii) completing the balance of the questionnaire by obtaining completed responses by fax or mail to a set of printed interview sheets. Data were provided by each of the firms under a promise of confidentiality. It was not uncommon for this process to involve more than a dozen points of contact (by telephone, fax or letter) between the current author or his research assistants and each of the firms being studied. Data were also collected on other matters about which there is insufficient space in this paper to report.

At the completion of the data collection process in New York during May 1997 telephone interviews had been completed for 125 firms, and completed interview sheets had been received from 96 firms. Comprehensive data sets (both the telephone interview and the written fax/interview sheets, combined) were completed for 94 firms. Thus, substantial data (covering between $50 \%$ to $100 \%$ of the items) was assembled for $46 \%$ of the population; comprehensive data sets (covering close to $100 \%$ of the data items) were assembled for $34 \%$ of the population. Basic identifying data were assembled for $100 \%$ of the population (273 firms).

In the case of Utah, detailed questionnaire surveys, covering the vast majority of data items, had been completed for 91 firms by the end of July 1998. Thus, the Phase Two survey sample constituted over $80 \%$ of the population. Complete "Phase One" census data (i.e., $100 \%$ of the basic identifying data) were assembled for all 116 firms in the population (i.e., the sample size for Phase One was $100 \%$ of the population size). In short, the basic data on Utah's bioscience technology industry were drawn from a completely comprehensive industry census, and the data on details of the behavior and performance of the firms were drawn from an extraordinarily high sample size, capturing the vast majority of the population.

The final data set assembled for the analysis below consisted of 184 records of valid data, drawn from 93 confirmed bioscience technology firms in New York State and 91 confirmed bioscience technology firms in Utah. One firm from New York had to be deleted from the final sample due to data quality problems, reducing the total from New York from 94 firms to 93 firms.

\subsection{Basic characteristics of the firms in the study sample}

Recognizing that not all entrepreneurial firms are necessarily small, and that not all small firms are necessarily entrepreneurial, the firms in the sample were divided up in to four categories, based upon a combination of their age and size, as pictured in Table 1.

The average size of the firms in the sample is 146 employees, although about $60 \%$ of the firms in the sample employ no more than 25 people, and only about $11 \%$ employ 300 or more people. The average age of firms in the sample is just over sixteen years; although at the time of the study $47 \%$ of the firms had been in existence for no longer than ten years and a full $24 \%$ had been in existence for no longer than five years. Eighteen percent were over 25 years old. Over $65 \%$ of the firms in the sample are either 
small (no larger than 25 people) or young (no older than 5 years). Almost one fifth of firms in the sample (17.5\%) are classic "start-up" firms (no larger than 25 people and no older than 5 years). In short, the bioscience technology industry as represented by this data set is predominantly young, small and entrepreneurial, with a significant minority of the industry constituted by true start-ups. Despite the fact that the bioscience technology industry is predominantly small, young and entrepreneurial, the average annual revenue per firm in this data set is over US\$35 million, and the average market value of the firms is almost US\$56 million.

Table 1. Classification of the Entrepreneurial Status of Firms in the Study $(\mathrm{n}=184)$.

\begin{tabular}{|c||c|c|}
\hline \multicolumn{1}{|c||}{ Size of the Firm } & \multicolumn{2}{c|}{ Age of the Firm } \\
$\leq 5$ years & $>5$ years \\
\hline \hline \multirow{2}{*}{$\leq 25$ people } & $\begin{array}{c}\text { Start-up firms } \\
(17.5 \% \text { of sample })\end{array}$ & $\begin{array}{c}\text { Small established firms } \\
(42.1 \% \text { of sample })\end{array}$ \\
\hline$>25$ people & $\begin{array}{c}\text { Large emerging firms } \\
(6.0 \% \text { of sample })\end{array}$ & $\begin{array}{c}\text { Large established firms } \\
(34.4 \% \text { of sample })\end{array}$ \\
\hline
\end{tabular}

The vast majority of firms in the sample (79\%) are privately held (i.e., their stocks are not publicly traded), and $85 \%$ are freestanding, independent firms (i.e., they are not subsidiaries of some other company). The majority of firms are therefore, we may infer, organizationally free to make strategic decisions. The fact that the industry is dominated by privately owned firms rather than publicly traded firms, interestingly stands in tension with the overwhelming emphasis in both the popular business press and the academic literature on publicly traded firms in what are now widely known as the "life-sciences" industries.

The single largest industry focus of the firms is medical devices technology (52\% of the sample), with $39 \%$ focused on biotechnology, $25 \%$ on pharmaceuticals, and $17 \%$ on bio-systems. The four industry categories are not discrete (i.e., a firm may be active simultaneously in more than one industry category) and almost one third of the firms are simultaneously active in more than one industry.

These data confirm that the population of firms that is the focus of this study is indeed appropriate for addressing the issues raised in the preceding discussion about the management of intellectual property by entrepreneurial technology firms.

\section{Analysis of Data}

All tables and figures included in this paper are original and were produced by the author based on the original empirical research reported here.

\subsection{Prominent place of intellectual property in entrepreneurial technology firms}

Managers of the firms included in the study were asked to estimate both the percentage of full-time-equivalent employees (i.e., the percentage of total person-hours per year worked 
by all employees combined "FTE") and the percentage of the CEO's time devoted to managing intellectual property. On average, across all firms in the sample, $14 \%$ of the CEO's time is devoted to managing intellectual property and $11 \%$ of FTE employment is devoted to the management of intellectual property. These results are broken down in Figure 1 according to the entrepreneurial status of each firm as defined in Table 1 above.

The most striking thing about these results is that intellectual property management occupies an extraordinarily large place in the work of the CEOs of the start-up firms (firms with no more than 25 FTE employees and doing business for no longer than 5 years), with the top managers of those firms devoting almost one fifth of their time to intellectual property matters. In other words, the CEOs of the start-ups devote double the amount of time to managing intellectual property than is the norm for large established firms in the bioscience-technology industries. These results are statistically significant ( $\mathrm{P}$ $=$ approx. 0.05 ). The start-up firms also devote a disproportionately large amount of the work-time of their employees to intellectual property: the percentage of total work time devoted to intellectual property by start-ups is over six times as great as the amount devoted by large established firms. These results are also statistically significant, with an almost zero probability that the variations may be explained by chance $(\mathrm{P}=0.0005)$.

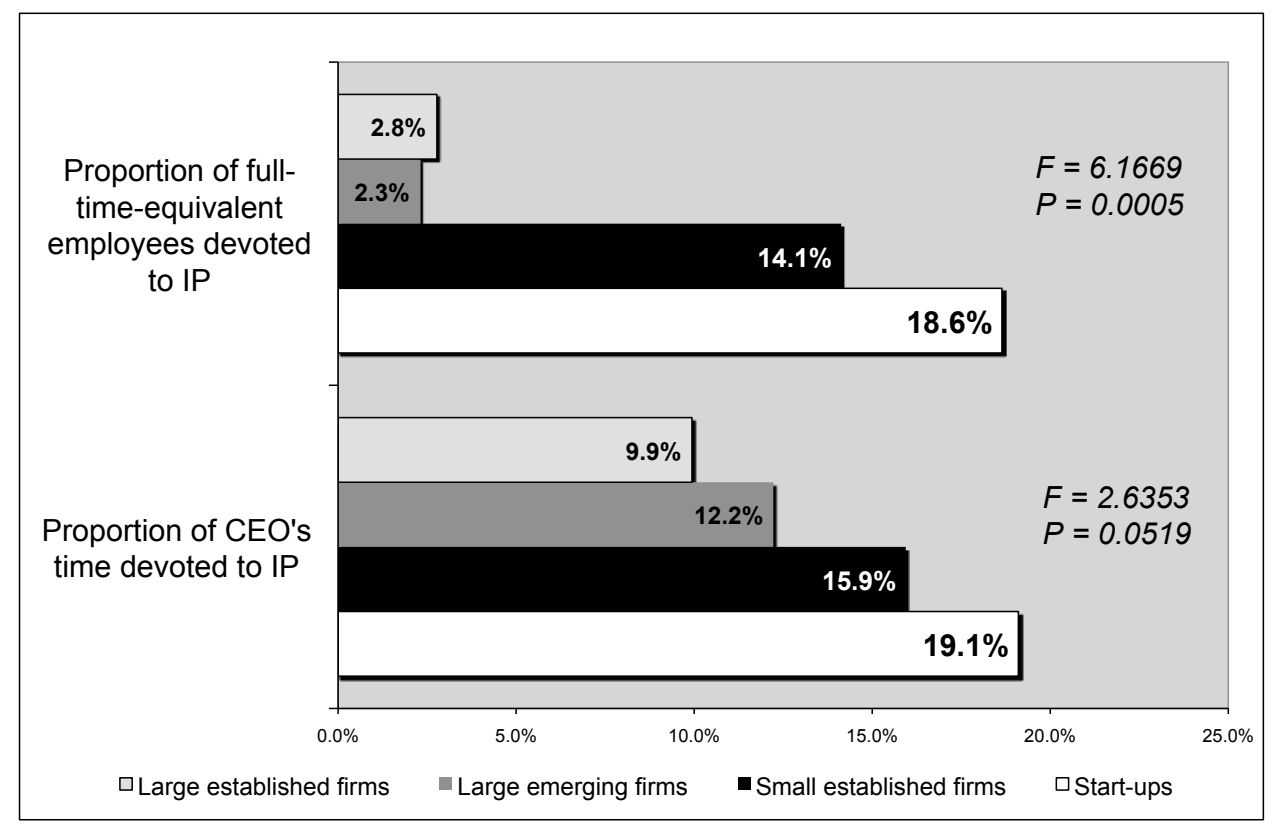

$F=$ F Ratio from one-way Analysis of Variance calculations. $P=$ probability that the results are not statistically significant.

Figure 1. Intellectual Property Management Practices of Managers and Employees.

In contrast to the concern expressed in some of the literature that intellectual property protection for technology is largely the "playground" of the larger more established firms, the data summarized here show that SMEs - at least those in "high technology" industries - are very much engaged in the world of intellectual property. In short, it appears that intellectual property occupies a prominent position in the business of small, young entrepreneurial technology firms, a position that is more prominent than is the case 
for large, established, mature technology firms (at least in the typically R\&D intensive bioscience technology industries).

\subsection{Influence of the enterprise's context on its intellectual property profile}

\subsubsection{Industry context}

Having observed that intellectual property management is at least as important to the work of small, young or entrepreneurial firms as it is to the work of larger established firms, we will now return to the triple question that lies at the core of this paper: what practices do firms actually adopt to protect their technology, what special shape do these practices take for entrepreneurial firms, and what forces seem to influence the adoption of one approach rather than other approaches that, in principle, may be available to a firm?

We will begin by looking at the context of the enterprise. As indicators of context we will examine both the industry to which a firm belongs and the degree to which it is internationally active in its business. The level of internationalization will be examined in two complementary ways: the level of formal collaboration between a firm and other organizations across international boundaries; and, the level of informal communication between the firm's people and people in organizations outside the home country.

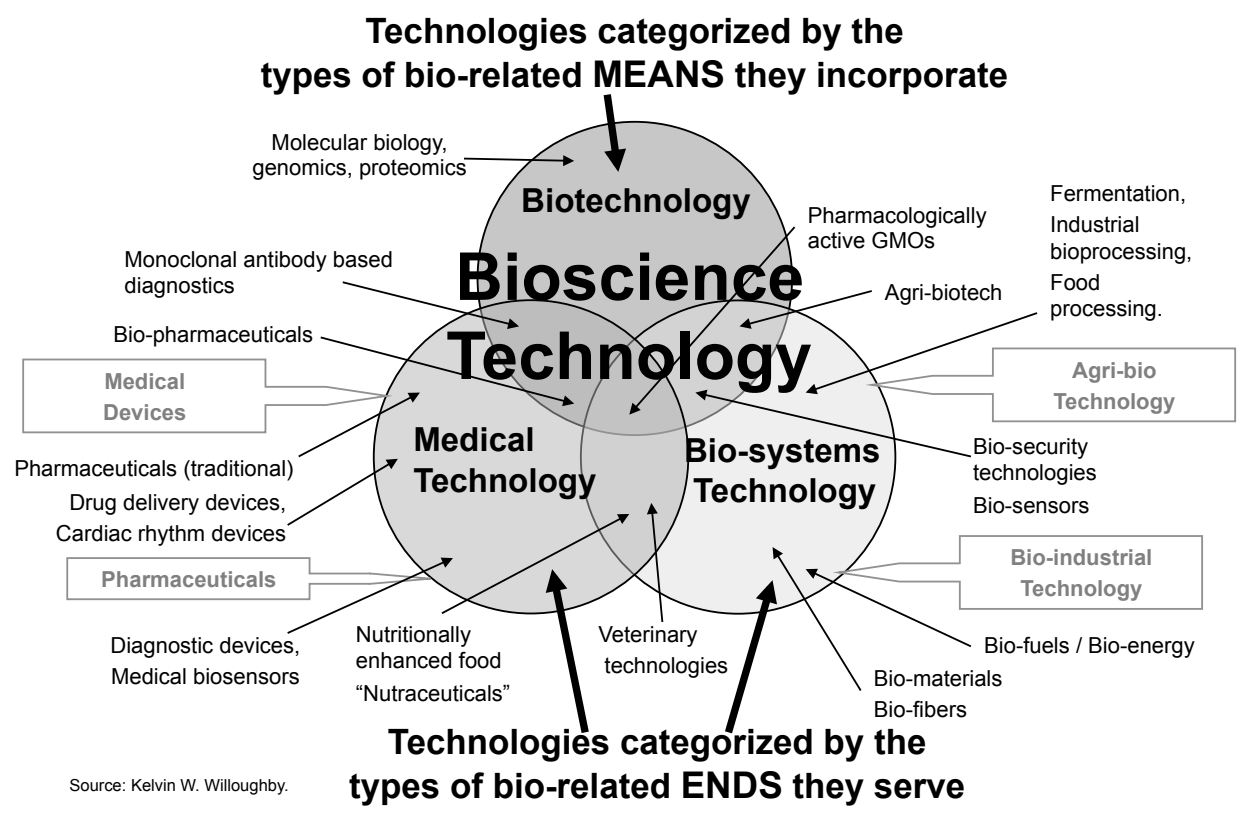

Figure 2. Industry classification system for bioscience-technology firms.

Each of the 184 firms included in the sample for this study was classified according to which of the following four industry categories it belonged: biotechnology, pharmaceuticals, medical devices, and bio-systems. A simplified graphical representation of the classification system is provided in Figure 2 that, among other things, illustrates that a firm may simultaneously belong to more than one industry group. Indeed, it turned 
out that almost one third of the firms in this study were simultaneously active in multiple industries. Hence, the sum of the percentages of firms in the study sample in each industry category is greater than 100 percent.

Following the basic industry classification exercise, data were then obtained from each firm included in the study sample regarding the repertoire of intellectual property elements constituting its intellectual property portfolio. In particular, the firms provided information on the number of patents, trade secrets, trademarks and copyright-protected items (mostly computer software inventions) in their inventory. Additionally, data were obtained on the number of licenses or options on licenses held by each firm for technology owned by other companies. The results are summarized in Table 2 and, to assist interpretation, are standardized relative to the number of people employed in each firm.

Table 2. Variations in intellectual property profiles across industry categories.

\begin{tabular}{|c|c|c|c|c|c|c|c|}
\hline & & mber & tellect & prope & tems $p$ & 5 peot & \\
\hline $\begin{array}{c}\text { Intellectual } \\
\text { property category }\end{array}$ & 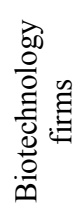 & 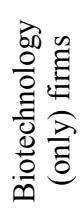 & 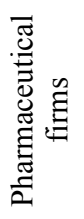 & 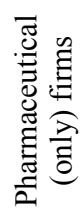 & 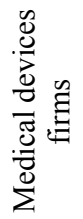 & 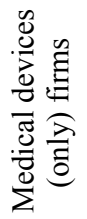 & 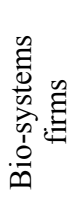 \\
\hline Patents & 9.7 & 20.5 & 14.5 & 15.5 & 15.6 & 7.6 & 30.4 \\
\hline Trade secrets & 34.4 & 28.5 & 23.5 & 37.5 & 21.2 & 55.9 & 27.3 \\
\hline $\begin{array}{c}\text { Copyright } \\
\text { protected items }\end{array}$ & 8.1 & 10.1 & 16.0 & 7.4 & 11.2 & 3.1 & 2.4 \\
\hline $\begin{array}{c}\text { Licenses \& } \\
\text { options }\end{array}$ & 6.5 & 7.0 & 2.8 & 6.4 & 2.3 & 5.8 & 9.5 \\
\hline Trade marks & 4.0 & 9.1 & 4.6 & 5.4 & 4.2 & 2.9 & 15.8 \\
\hline $\begin{array}{c}\text { Number of firms in } \\
\text { each industry category }\end{array}$ & 71 & 29 & 46 & 22 & 96 & 74 & 31 \\
\hline $\begin{array}{l}\text { Percentage of firms in } \\
\text { each industry category }\end{array}$ & $39 \%$ & $16 \%$ & $25 \%$ & $12 \%$ & $52 \%$ & $40 \%$ & $17 \%$ \\
\hline
\end{tabular}

Table 2 reveals considerable variation across industry groups in the manner in which intellectual property is configured by firms. For example, firms that specialize only in medical devices-without also being active in the "life sciences" (biotechnology and other fields, including pharmaceuticals, drawing heavily upon biological science) - tend to rely much more heavily than others on trade secrets to protect their technology. On the other hand, firms that specialize only in biotechnology - i.e., they practice biotechnology without also being active in other industry groups (perhaps we could call these the "pure biotechnology firms") - tend to rely more heavily than most other firms, with the exception of bio-systems firms, on patents to protect their technology. The "pure" 
medical devices firms - perhaps not surprisingly given their relatively strong reliance upon trade-secret protection - exhibit the lowest propensity of all for patent protection. The use of copyright as a method for protecting their technology (generally for computer software inventions that form part of a complex product or service) appears to be most prominent among the firms that are active, in one way or another, within the medically oriented industries. Trademarks, interestingly, are used most intensively (measured on a per-person-employed basis) by firms active primarily in bio-systems and, to a lesser extent, in biotechnology. Finally, Table 2 reveals that bio-systems firms exhibit the highest number of intellectual property items per person for all types of intellectual property except copyright. It appears, in short, that bio-systems firms are more intellectual property-intensive than firms in other bioscience-technology industries. Variations across industry groups are also observable in the propensity of firms to license in technology from other firms, with bio-systems firms and biotechnology firms being the most prominent.

The industry to which a technology firm belongs appears, on the basis of the evidence provided in Table 2, to be an important factor in the choice or determination of its intellectual property profile. Industry matters.

\subsubsection{International context}

Another contextual factor-besides industry membership - with potential effects on the intellectual property management of a technology firm is the extent to which it is internationalized in its business. One way to operationalize the internationalization of a firm for the purposes of research is to measure the degree to which it engages in formal collaboration (e.g., joint ventures, collaborative research projects or collaborative product development) with organizations in other countries. For this purpose an "index of international formal collaboration" was calculated for each firm in the study sample by counting the total number of organizations in foreign countries (in 8 different organizational categories) with which the firm formally collaborated during the most recent one-year period. Firms were then divided in to two groups based upon whether their index of international formal collaboration was above average or below average for the study sample. The average number of items of intellectual property of each type possessed by each firm was then calculated for the above-average group and the belowaverage group. The results are presented graphically in Figure Three.

Figure 3 reveals an inverse relationship between the propensity of firms to collaborate formally with other organizations internationally and the level of intellectual property protection per person. This relationship holds for all categories of intellectual property and is statistically significant for all categories except licenses and options on licenses. The statistical significance of the relationship is especially strong for trade secrets and patents. At this stage we can only speculate about the reasons for this inverse relationship. Nevertheless, we can say that there appears to be something about the circumstances of technology firms who conduct their business in a relatively self-reliant or organizationally discrete manner (internationally) that leads them to protect their technology through intellectual property more heavily than other firms.

Figure 3 also reveals that firms exhibit a general preference - or, at least, a practical bias - towards using trade secrets rather patents for the protection of their technology. 
Among other things, this affirms the observation of other researchers that the old notion of intellectual property management mostly being about the "administration of patents" is not applicable (if it ever was). It also provides empirical support for those authors cited earlier in this paper who assert that trade secret protection ought to be considered as a viable, if not sometimes superior, form of intellectual property protection for firms over patents.

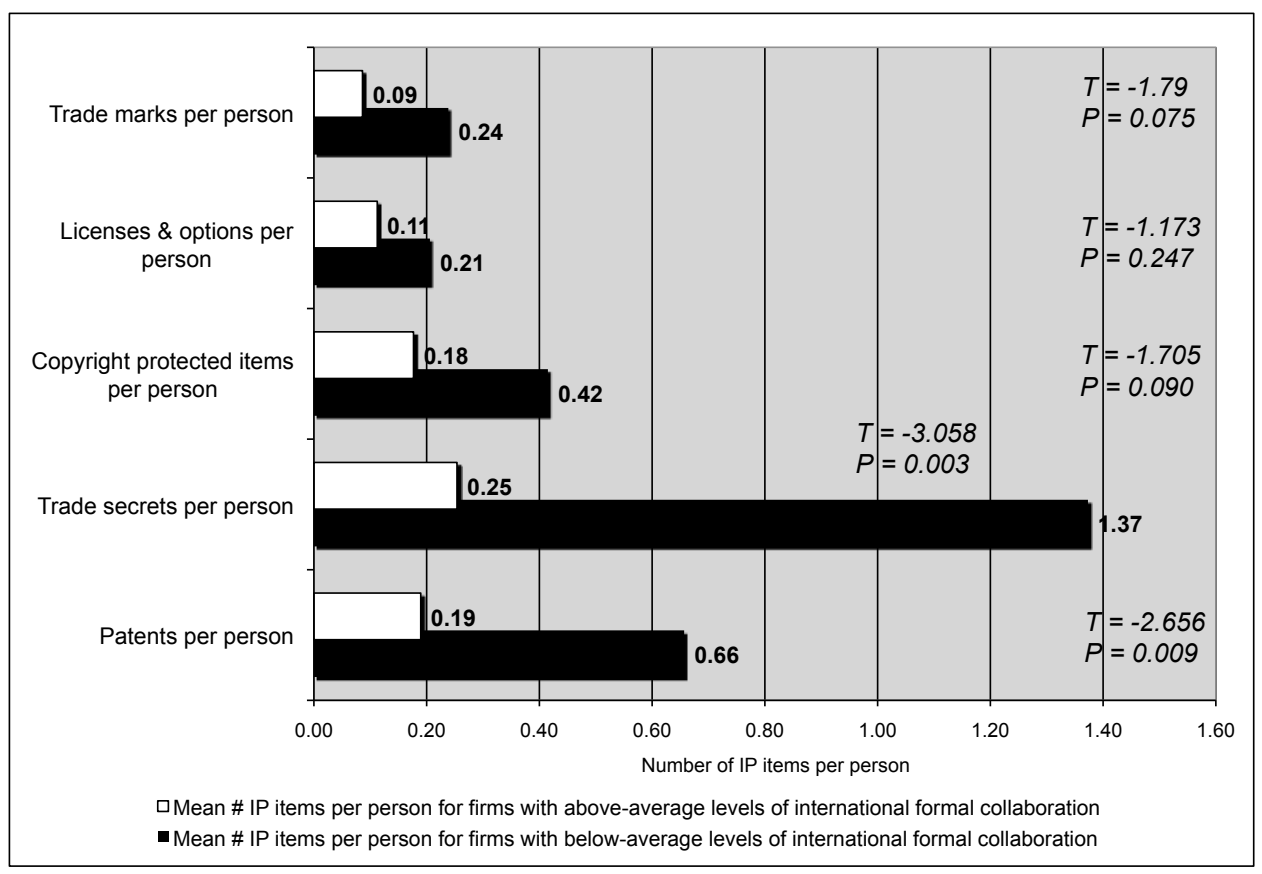

Figure 3. Relationship between international formal collaboration and the intellectual property profile of firms. ${ }^{* *}$

The results expressed in Figure 3 also reveal that copyright actually plays a significant role in the intellectual property portfolios of technology firms (biosciencetechnology firms, in this case), despite the fact that many commentators assume that copyright is mainly only applicable in the aesthetic, artistic and literary industries related to music, movies, books or the visual arts. The important place of computer software as a component of the products and services of the bioscience technology enterprises is the reason for this interesting feature in the data. Computer software is protected by copyright in most countries. ${ }^{\dagger \dagger}$

** Note: In Figure 3 and all subsequent figures " $\mathrm{T}$ " is the T Ratio from the calculation of the difference of means, assuming unequal variances and, unless otherwise indicated, "P" is the probability that the differences between the means are not statistically significant.

$\dagger$ See, for example, Article 4 of the WIPO Copyright Treaty, adopted in Geneva on December 20 , 1996 [World Intellectual Property Organization (1996)]: "Computer programs are protected as literary works within the meaning of Article 2 of the Berne Convention. Such protection applies to computer programs, whatever may be the mode or form of their expression." The Berne Convention is the Berne Convention for the Protection of Literary and Artistic Works, adopted at Paris on September 9, 1886, as revised and amended (1979) [see World Intellectual Property Organization (1979)]. 
An alternative way to operationalize the internationalization of a firm for the purposes of research is to measure the degree to which it's employees engage in informal communication (i.e., personal interactive talking) with people in organizations in other countries. For this purpose an "index of international informal communication" was calculated for each firm in the study sample by counting the total number of organizations in foreign countries (in 8 different organizational categories) which have people with whom the firm's employees have engaged in significant informal communication during the previous year. Firms were then divided in to two groups based upon whether their index of international informal communication was above average or below average for the study sample. The average number of items of intellectual property of each type possessed by each firm was then calculated for the above-average group and the below-average group. The results are presented graphically in Figure Four.

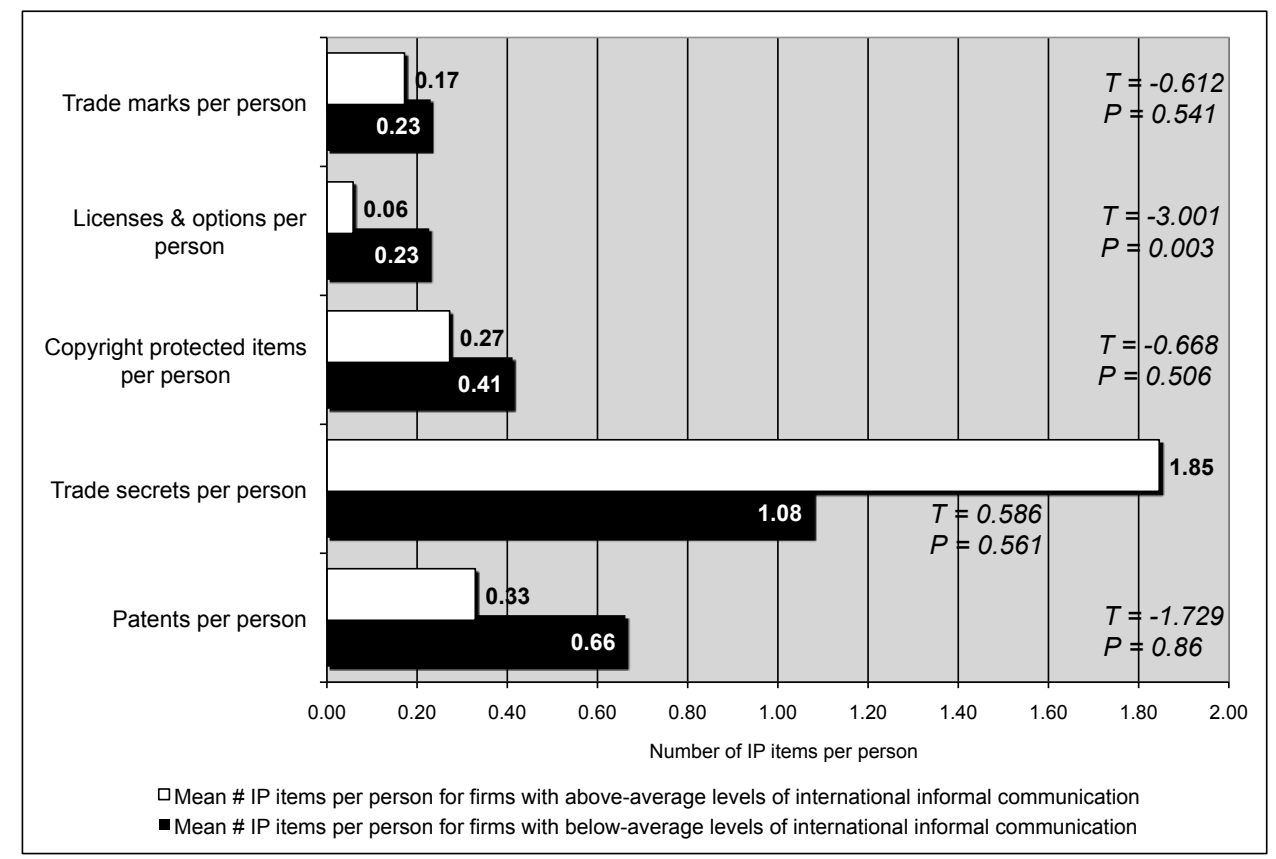

Figure 4. Relationship between international informal communication and the intellectual property profile of firms.

In most respects the results for intellectual property protection profiles in Figure 4 follow the overall pattern observable in Figure 3 (with differences in the scale of the variations) although, in contrast to the case with formal collaboration, the statistical significance of the relationship for informal communication is questionable except for patents and licenses. Nothwithstanding these caveats, there is one remarkable feature in Figure 4: firms whose people engage in above average levels of international informal communication rely upon trade secret protection much more heavily than firms with people whose levels of engagement in international informal communication is lower 
than average. ${ }^{*}$ In other words, the more that the firms in the study sample make formal arrangements to protect their technology lawfully through the adoption of trade secrets the more that their employees exhibit the freedom to talk with people in other organizations worldwide (including competitors).

At first glance this result would seem to be counterintuitive; we would perhaps naturally expect a firm that emphasized secrecy as an important part of the protection strategy for its technology to likewise discipline its employees to refrain from open communication with people from other organizations, for fear that its secrets might be lost or compromised. Put another way, we might naturally expect an emphasis on secrecy for proprietary technology to undermine a firm's propensity for open communication, a behavioral quality that one would in turn associate with "open innovation." The facts, however, ironically suggest the opposite.

We can only speculate at this stage about the reasons for this remarkable pattern. It seems likely that when firms are sufficiently disciplined to follow the proper procedures required under the laws of most jurisdictions to obtain the legal rights associated with the protection of technological know-how through secrecy they thereby reduce uncertainty. When employees of a technology firm receive explicit and unambiguous instructions from their managers about which know-how is to be protected as a trade secret and which know-how is not subject to such constraints, employees are then free to talk with outsiders without having to worry about whether or not they might inadvertently violate their employer's secrecy policy.

In short, when a firm's managers take care to properly follow the administrative requirements under law pertaining to trade secrets (e.g., by explicitly defining the trade secrets and by providing unambiguous and appropriate notice to employees, visitors and research partners, etc.) they create more freedom for their employees. The apparent paradox is that, if trade secrets are properly managed accordingly to law, then by placing heavier emphasis on secrecy for the protection of technology, the managers of technology companies may facilitate more open inter-organizational communication by their employees. While it is difficult to speculate about the nature and direction of the causality between the various behaviors we can nevertheless observe from the results reported in Figure 4 that there is an association between the international connectedness of a firm's people and the level of reliance upon trade secrets for protecting its technology.

The level of internationalization of a firm's activities, whether measured by its international formal collaborations or its international informal communications, is important for a firm's intellectual property profile. International factors matter.

In summary, Figures 3 and 4 indicate that the international activity of firms is associated with the intellectual property profile of firms. Additionally, as shown by the results in Table 2, variations in the profiles and levels of intellectual property protection for technology occur along with variations in the industries to which firms belong. Context matters.

赫 If the trade secret data are expressed as trade-secrets-per-firm rather than trade-secrets-per-person then the relationship is statistically significant. The mean number of trade secrets possessed by firms with above-average levels of international informal communication is 45.6 , versus 16.1 for firms with below-average levels of international informal communication $(\mathrm{T}=1.683, \mathrm{P}=0.101)$. 


\subsection{Influence of the enterprise's organizational profile on its intellectual property profile}

Having investigated the relationship between a firm's context (both industry context and international context) and its intellectual property profile we will now look at the potential relationship between a firm's organizational profile and its intellectual property profile. As indicators of a firm's organizational profile we will consider its size, its entrepreneurial status and its financial profile.

\subsubsection{Size}

Figure 5 portrays the differences in the intellectual property profile of firms in the study sample according to their size. "Small firms" refers to firms with no more than 25 fulltime-equivalent employees and "large firms" refers to firms with greater than 25 fulltime-equivalent employees. As indicated by the results of the $\mathrm{T}$ tests, which are also reported in Figure 5, the differences are statistically significant for all categories of intellectual property, with the exception of copyright (where, while the inverse relationship between firm size and the number of intellectual property per person is still clearly observable, the $\mathrm{P}$ score is relatively large).

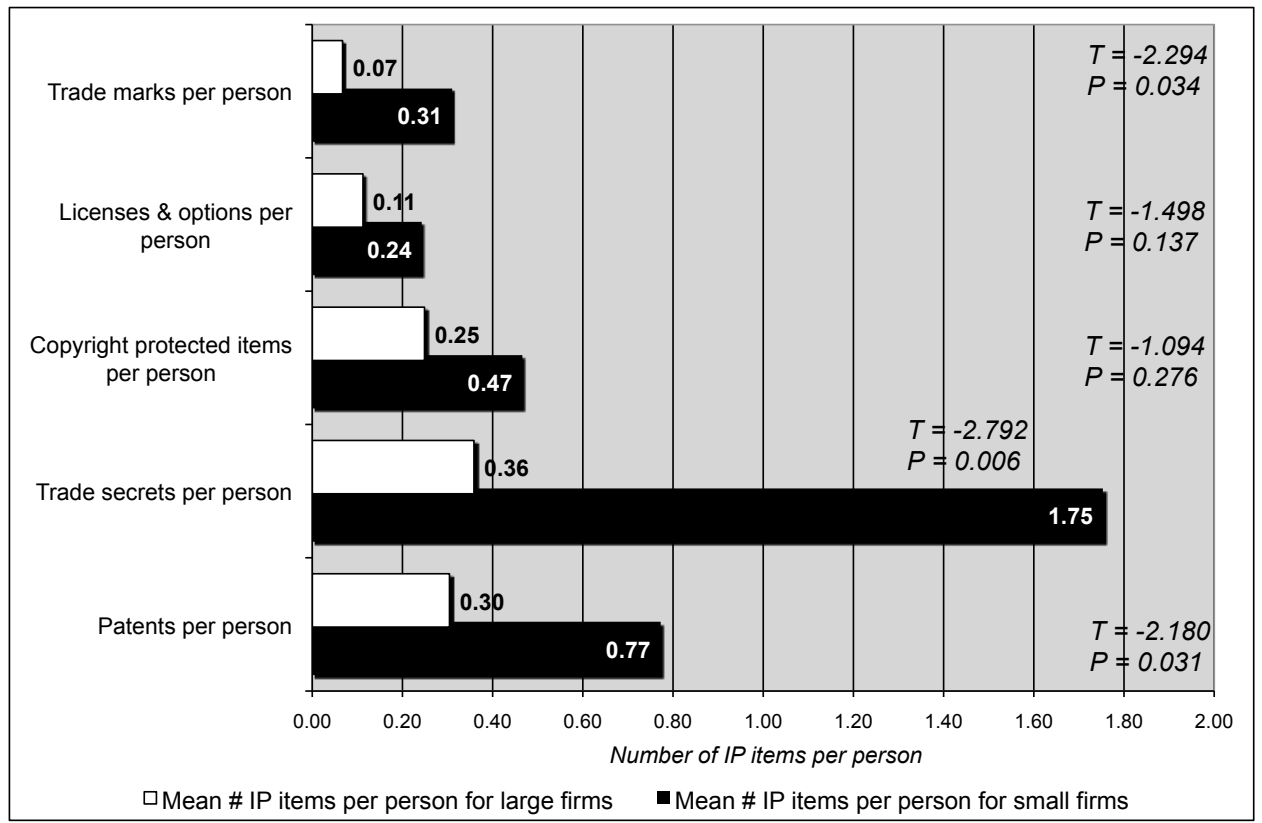

Figure 5. Relationship between the size of firms and their intellectual property profile.

Several observations are apposite. First, contrasts in the weight given by firms to each particular kind of intellectual property protection for technology are significantly more marked for small firms than for large firms. Second, the emphasis placed on trade secrecy as a form of protection is much greater (in fact, almost 5 times greater) for small firms over large firms. This accords with the observation made by a number of authors surveyed earlier in this paper who emphasize secrecy as the preferred form of protection 
amongst SMEs. The statistical significance of this result is particularly strong ( $\mathrm{P}=$ 0.006). However, while it is true that the data reported here do confirm that small firms generally possess more trade secrets rather than patents, the results in Figure 5 do not support the dominant view in the literature that small firms place less emphasis on patents than do large firms. In fact-and this is the third observation - the small firms surveyed in this study also rely more heavily upon patent protection than do large firms (when the numbers are standardized as patents-per-person to make comparisons more meaningful). Thus, the small firms here (all of which are technology firms) make more intensive use of both patent protection and trade secret protection than do the large firms. The fourth observation that may be drawn from the Figure is closely related to the third: the small firms represented here make heavier use than do large firms of all forms of intellectual property (on a per-person basis), not just trade secrets and patents. Thus, it appears that when the analysis is restricted to technology firms (as is the case for this study), rather than firms from a wide variety of industries regardless of whether or not they are technology intensive, small firms are generally more intellectual propertyintensive than large firms.

Table 3. Correlation matrix: Natural logarithm of firm size and categories of intellectual property.

\begin{tabular}{|c|c|c|c|c|c|c|}
\hline Variables & $\begin{array}{l}\text { Log of } \\
\text { firm size }\end{array}$ & $\begin{array}{l}\text { Patents } \\
\text { per person }\end{array}$ & $\begin{array}{c}\text { Trade } \\
\text { secrets per } \\
\text { person }\end{array}$ & $\begin{array}{c}\text { Copyright } \\
\text { protected } \\
\text { items per } \\
\text { person }\end{array}$ & $\begin{array}{l}\text { Licenses } \\
\text { \& options } \\
\text { per person }\end{array}$ & $\begin{array}{c}\text { Trade } \\
\text { marks per } \\
\text { person }\end{array}$ \\
\hline Log of firm size & 1.0000 & & & & & \\
\hline Patents per person & $\begin{array}{l}-0.1840 \\
(0.0191)\end{array}$ & 1.0000 & & & & \\
\hline Trade secrets per person & $\begin{array}{l}-0.1577 \\
(0.0450)\end{array}$ & $\begin{array}{c}0.3129 \\
(0.0001)\end{array}$ & 1.0000 & & & \\
\hline $\begin{array}{l}\text { Copyright protected items } \\
\text { per person }\end{array}$ & $\begin{array}{l}-0.0988 \\
(0.2109)\end{array}$ & $\begin{array}{c}0.0132 \\
(0.8672)\end{array}$ & $\begin{array}{c}0.1946 \\
(0.0131)\end{array}$ & 1.0000 & & \\
\hline $\begin{array}{l}\text { Licenses \& options per } \\
\text { person }\end{array}$ & $\begin{array}{l}-0.2349 \\
(0.0026)\end{array}$ & $\begin{array}{l}-0.0311 \\
(0.6941)\end{array}$ & $\begin{array}{l}-0.0366 \\
(0.6436)\end{array}$ & $\begin{array}{c}0.0530 \\
(0.5029)\end{array}$ & 1.0000 & \\
\hline Trade marks per person & $\begin{array}{l}-0.2119 \\
(0.0068)\end{array}$ & $\begin{array}{c}0.0254 \\
(0.7485)\end{array}$ & $\begin{array}{c}0.0185 \\
(0.8156)\end{array}$ & $\begin{array}{c}0.0215 \\
(0.7858)\end{array}$ & $\begin{array}{c}0.4331 \\
(0.0001)\end{array}$ & 1.0000 \\
\hline
\end{tabular}

Note: The primary number in each cell is the standard coefficient of correlation (R); the number in parentheses is the probability $(\mathrm{P})$ that the correlation is not significant.

Given the focal concern exhibited in the literature about the relationship between firm size and intellectual property, additional statistical analyses were conducted to examine the robustness of the relationships illustrated in Figure 5. Correlations between the natural logarithm of firm size (in which the size variable is normally distributed) and the five intellectual property variables were calculated, together with the probability of significance. The results, summarized in Table 3, affirm the results from the comparison of means summarized in Figure 5. They also underline the observation from Figure 5 that, across their intellectual property portfolios, firms tend to treat trade secrets and patents as complementary rather than competing forms of intellectual property protection. 
Additionally, the correlation between the natural logarithm of firm size and the "number of IP items per person" (a compound variable which is the simple sum of all items of individual of intellectual property in each category for each firm - patents, trade secrets, copyright-protected items, trade marks, and licenses and options - divided by the full-time-equivalent number of employees in each firm), was calculated for the data set. The results, summarized in Table 4, show that there is a statistically significant inverse relationship between the size of firms and the aggregate number of intellectual property items (of all types) per person. The probability that this relationship is due to chance alone is extremely small no matter whether the correlation is calculated using the standard coefficient of correlation $(\mathrm{P}=0.0009)$, Kendall's Tau $(\mathrm{P}<0.0001)$ or Spearman's Rho $(\mathrm{P}<0.0001)$. The result is robust.

Table 4. Correlation between the natural logarithm of firm size and the aggregated number of intellectual property items per person.

\begin{tabular}{|c||c|}
\hline Description of statistic & Result \\
\hline \hline Number of firms included in calculations (N) & 162 \\
\hline Degrees of freedom (DF) & 161 \\
\hline Mean (IP items per person) & 2.634 \\
\hline Standard deviation (aggregated IP items per person) & 5.278 \\
\hline Minimum (aggregated IP items per person) & 0.00 \\
\hline Maximum (aggregated IP items per person) & 41.75 \\
\hline Lower 95\% & -0.3969 \\
\hline Upper 95\% & -0.1086 \\
\hline Standard coefficient of correlation (R) & -0.2585 \\
(Probability (P) in parentheses) & $(0.0009)$ \\
\hline Kendall's Tau coefficient of correlation & -0.3064 \\
(Probability (P) in parentheses) & $(<0.0001)$ \\
\hline Spearman's Rho coefficient of correlation & -0.4308 \\
(Probability $(P)$ in parentheses) & $(<0.0001)$ \\
\hline
\end{tabular}

The general result, which holds true no matter which form of statistical analysis is adopted, is that the level of intellectual property protection per person is greater for the smaller firms in the study than it is for the larger firms in the study. The size of a firm (measured by its employment level) appears, on the basis of the evidence assembled here, to be an important factor in the choice or determination of its intellectual property profile. Size matters.

\subsubsection{Entrepreneurial status}

A second vantage point from which we may examine the impact of the organizational profile of a firm on its intellectual property profile is that of its entrepreneurial status. Using the classification system defined in Table 1, each firm was allocated to one of the following four categories: start-up firm, small established firm, large emerging firm and large established firm. The intellectual property profile of each of the four groups of firms was then calculated and plotted as shown in Figure Six. The picture when both size 
and age is considered together is more complex than the one presented when only size is considered.

Figure 6 shows that small established firms (no larger than 25 people, but older than five years) make the most intensive use of intellectual property protection for their technology across all types of intellectual property: patents, trade secrets, copyright and trademarks. They are also, by a large margin, the heaviest users of trade secrets; it appears that as small firms age (moving beyond five years old) they tend to increase the relative weight they place on trade secret protection in contrast to patent protection. The number of trade secrets per person owned by small established firms is about 6.5 the number owned by large established firms.

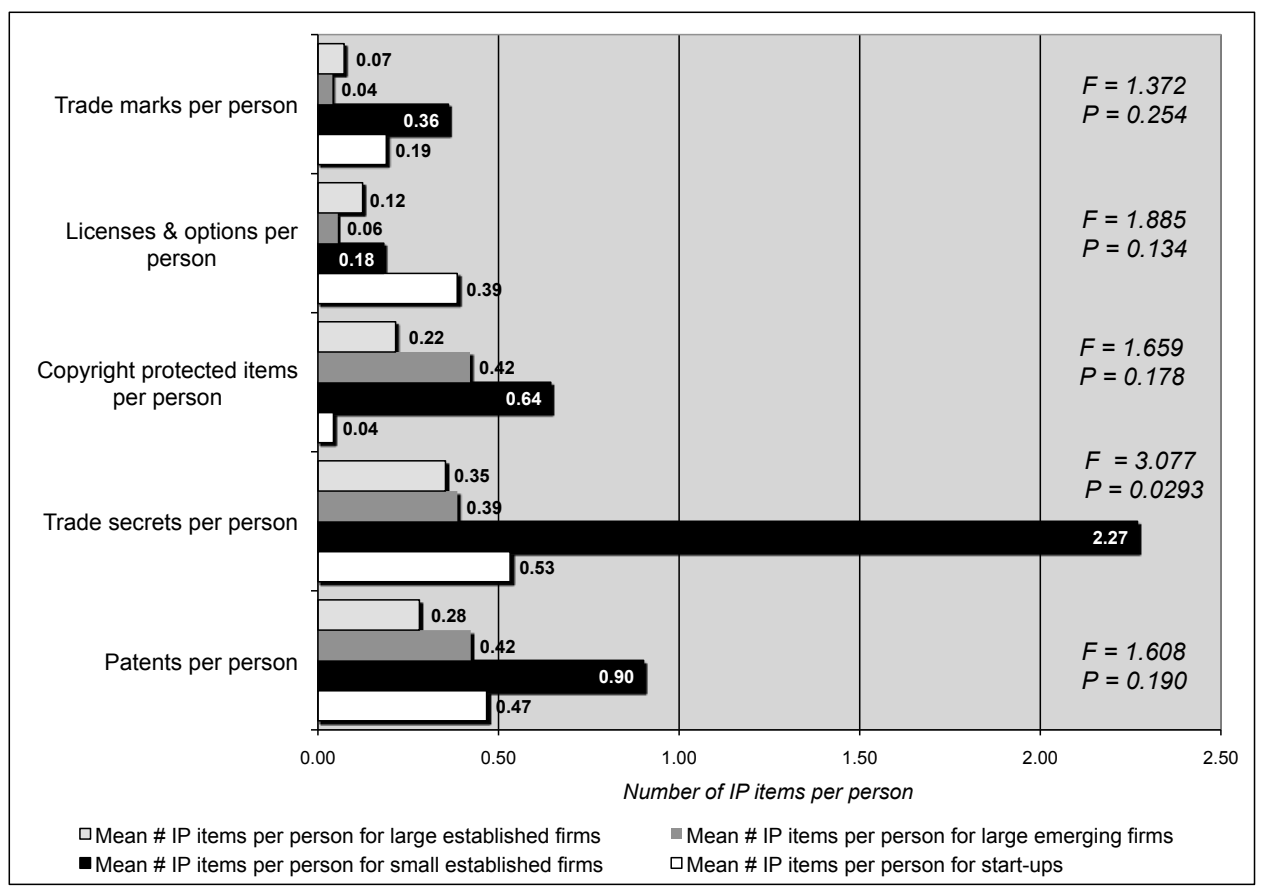

$F=$ F Ratio from one-way Analysis of Variance calculations. $P=$ probability that the results are not statistically significant.

Figure 6. Relationship between the entrepreneurial status and intellectual property profile of firms.

The start-ups (five years or younger and no larger than 25 people) are the second most intensive users of intellectual property protection for all categories except copyright, where they are the least intensive group. The start-ups are also the most reliant, proportionally (calculated on a per-person basis), upon licensing in technology from other companies. Figure 6 suggests that when they are very young small firms seek to facilitate building up their technological capability by licensing in technology from other organizations; but that, after they mature somewhat (perhaps after several years), they reduce their reliance upon externally sourced technology in favor of generating their own proprietary technology.

In contrast, Figure 6 suggests that as the large emerging firms (larger than 25 people, but no older than five years) mature they move in the opposite direction by increasing 
their reliance upon externally sourced technology; large firms that are older than five years license in technology from external sources twice as heavily (measured as licenses per person) than do large firms that are younger than five years. Large emerging firms are also relatively intensive in their use of copyright (to protect software inventions).

As revealed by the $\mathrm{F}$ ratios and $\mathrm{P}$ values in Figure 6, the statistical significance of these results is weaker than for the results based on firm size alone, as discussed above. The one exception lies with trade secrets, where the relationship between entrepreneurial status and the number of trade secrets per person is clearly statistically significant.

The entrepreneurial status of a firm (measured by a combination of its employment level and its age) appears, on the basis of the evidence provided in Figure 6, to be an important factor in the choice or determination of its intellectual property profile - at least when it comes to the adoption of trade secret protection as part of its strategy. Entrepreneurial status matters.

\subsubsection{Financial profile}

A third vantage point from which we may examine the impact of the organizational profile of a firm on its intellectual property profile is that of its financial profile-in particular, its expressed strategy for raising the funding necessary to operate. Using established concepts from the literature on entrepreneurial finance, the firms in the sample were classified as belonging to either a "high-bootstrapping" group or a "lowbootstrapping" group (for a review of the pertinent literature and for a detailed exposition of these terms, see Willoughby [2008]). In contrast to conventional formal sources of finance for entrepreneurial technology firms - which include bank loans (private debt) and other forms of private debt financing, venture capital investments (private equity) or equity capital raised from the public stock markets- "bootstrap" finance is funding for the operation and development of a firm that comes from typically low-profile sources such as the founders' personal funds, grants, government loans, "sweat equity" and revenue generated by running the business. We could say that bootstrap financing is a kind of informal bottom-up approach to financing; and while it has the disadvantage that firms following this approach sometimes struggle with the problem of being undercapitalized (according to the received logic of contemporary financial orthodoxy), and hence being forced to run on a "shoe string" (i.e., on a bootstrap), it is often the only form of financing available to entrepreneurial technology firms - since both banks and venture capitalists are usually not willing to take risks on such early-stage firms. In short, technology firms often have no choice but to rely upon bootstrap finance, whatever the theoretical advantages of more formal and high-level externally sourced capital investment might be.

Detailed information on its sources of finance was collected for each firm in the study sample and the percentage of finance derived from bootstrapping was calculated for each firm. Firms that obtained at least half of their funding from bootstrap sources were classified as high-bootstrapping firms and the rest were classified as low-bootstrapping firms. The intellectual property profiles of each category of firms were then calculated and the results were graphed to produce Figure Seven.

Figure 7 reveals that low-bootstrapping firms embrace patents as a form of intellectual property protection for their technology at double the rate at which high- 
bootstrapping firms do so. In other words, relying heavily upon formal "high quality" external financing - from venture capitalists, the public markets or banks - is associated with a preference for patents. In contrast, the other categories of intellectual property (besides patents, and also trade secrets, where the behaviors of high-bootstrapping and low-bootstrapping appear to be similar) are embraced more intensively by highbootstrapping firms. High-bootstrapping firms also exhibit a stronger tendency to license in technology from elsewhere (measured as licenses per person) than low-bootstrapping firms. Despite the fact that low-bootstrapping firms are much more patent-intensive in their strategies, both low-bootstrapping firms and high-bootstrapping firms actually place more emphasis on trade secret protection than patent protection. This observation affirms the point of view adopted by a number of the writers reviewed earlier in this paper, and as supported by empirical evidence cited in Figure 5 and Table 3, that a firm's choice of patents as a vehicle for protecting its technology is not incompatible with simultaneously also making heavy use of trade secret protection.

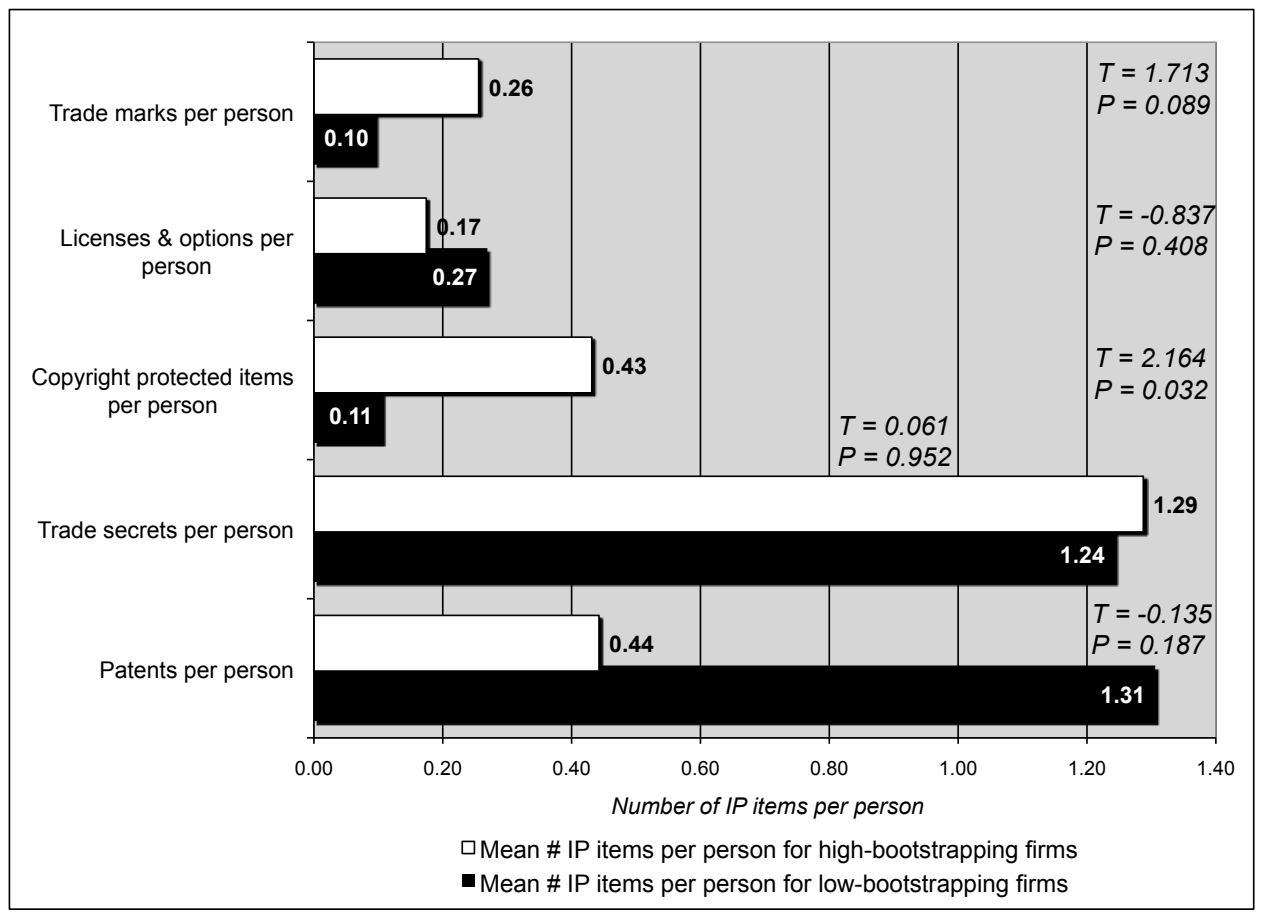

Figure 7. Bootstrapping and the intellectual property profile of firms.

The statistical significance of these results differs between variables, ranging from clearly significant in the case of trade marks and copyright, to questionable in the case of patents $(\mathrm{P}=0.19)$ and insignificant in the cases of trade secrets and licenses. Nevertheless, given that the absolute difference between the per capita reliance upon patents of low-bootstrapping firms and high-bootstrapping firms is so dramatic, and given that the vast majority of firms in the population are captured in the study sample, it would appear prudent to take the differences seriously and to perhaps explore this matter in more depth in a later study. Subject to these caveats, it appears reasonable to conclude 
that the financial profile of a firm (measured by whether it adopts a high-bootstrapping or a low-bootstrapping approach to financing its operations and development) appears, on the basis of the evidence provided in Figure 7, to be an important factor in the choice or determination of its intellectual property profile. Financial strategy matters.

In summary, all three indicators of a firm's organizational profile analyzed above appear pertinent to intellectual property management: Figure 5 (combined with Tables 3 and 4) indicates that variations in the size of firms are associated with variations in the profiles and levels of the intellectual property protection for their technology; Figure 6 indicates that variations in the entrepreneurial status of firms are associated with variations in the profiles and levels of the intellectual property protection for their technology; and Figure 7 indicates that variations in the financial profiles of firms are associated with variations in the profiles and levels of the intellectual property protection for their technology. Organizational profile matters.

\subsection{Influence of the enterprise's corporate goals on its intellectual property profile}

Having investigated the relationship between the industry context, international context, size, entrepreneurial status and financial profile of a firm and its intellectual property profile, the role of corporate goals will now be considered. This paper will focus on one indicator of a firm's corporate goals: its level of commitment to the production of goods and services rather than remaining primarily a research firm, design firm, investment firm, trading enterprise or holding company of some kind. In other words, the firm's engagement in commercialization of "downstream" products and services based on its technology will be considered as an indicator of its corporate goals. 
Figure 8. Relationship between production intensity (\% of FTE employees) and the intellectual

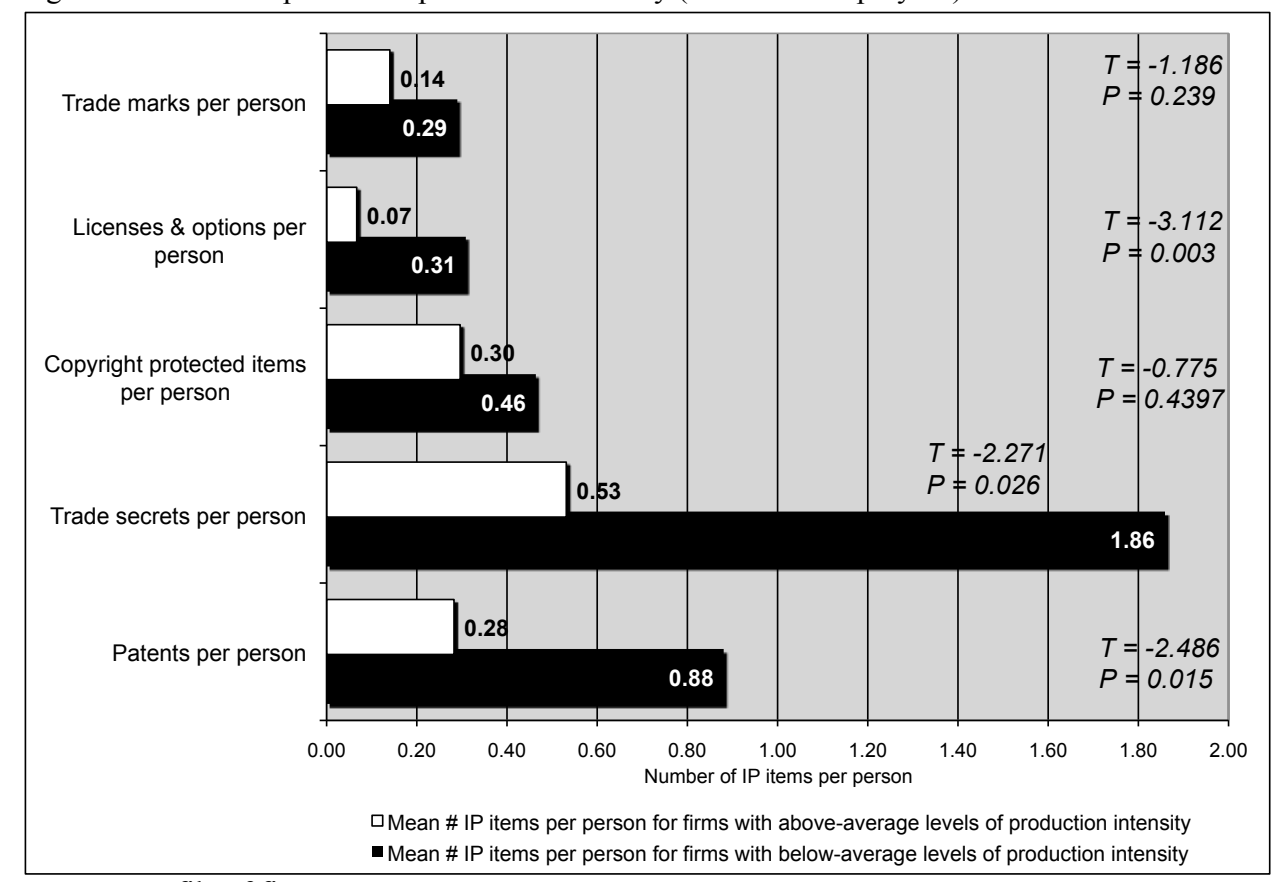

property profile of firms.

In this paper this factor is measured in two ways: the percentage of a firm's full-timeequivalent employees devoted to production activities (including the production of both tangible goods and services); and, the percentage of a firm's annual spending classified as COGS (cost of goods sold). In order to operationalize the first of these approaches, all firms in the study sample were classified as either those with above-average levels of production intensity (i.e., with an above-average percentage of a firm's full-timeequivalent employees devoted to production activities) or those with below-average scores for the same variable. In order to operationalize the second of these approaches all firms in the study sample were classified as either those with above-average COGS or those with below-average COGS, based upon financial and accounting data obtained confidentially from each firm directly. The intellectual property profiles for each of these groups were then graphed to produce the results shown in Figures Eight and Nine. 
Figure 9. Relationship between the intensity of spending on production activities and the

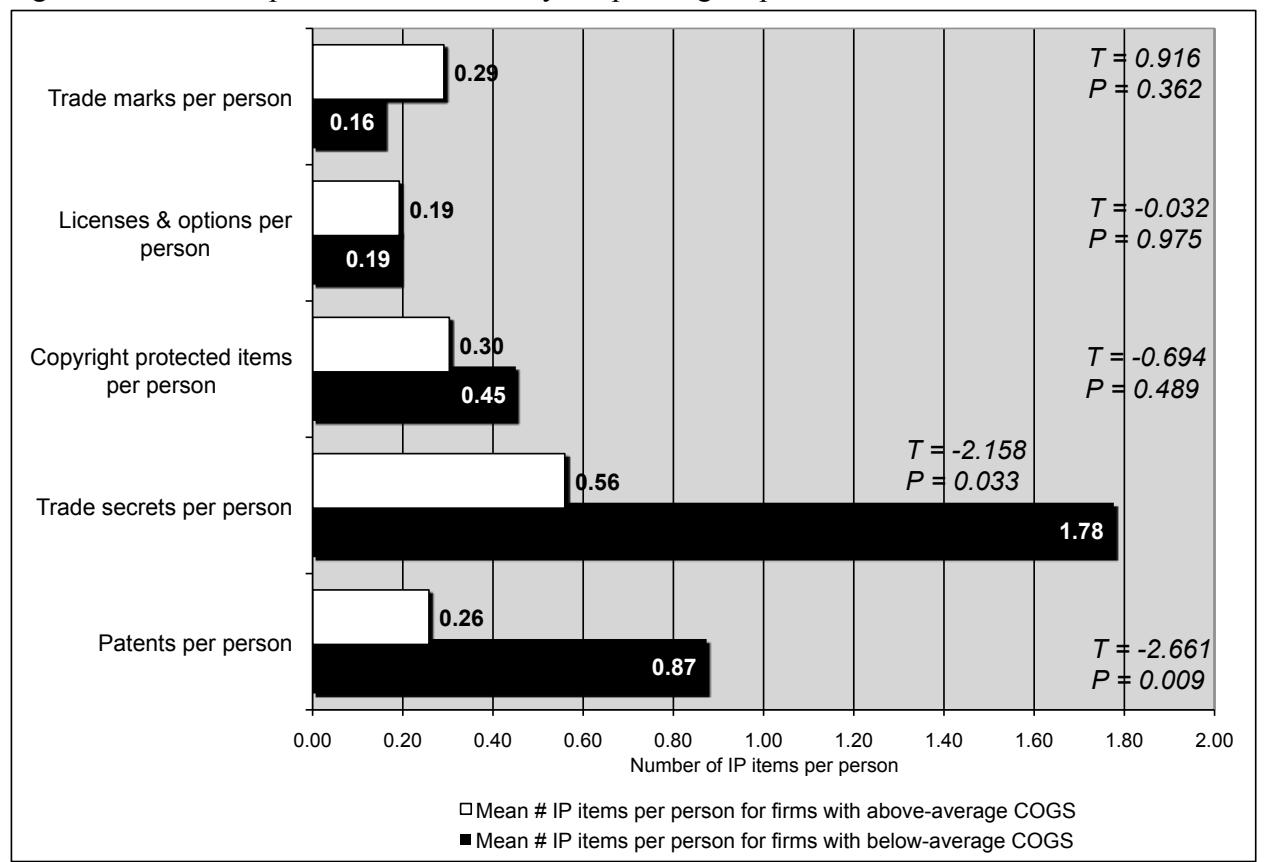

intellectual property profile of firms.

The results for Figure 8 and Figure 9 tell a similar story: no matter by which method production intensity is measured, whether by the allocation of human resources or by spending, the group of firms with above-average percentages of their activities devoted to production of goods and services exhibits lower levels of intellectual property protection. The obvious exception to this rule seems to lie with trademarks, but only when measured according to spending rather than allocation of employee's time. It also appears that the propensity of firms to license in technology from other firms is not affected by their production intensity. Despite these qualifications, it appears overall that the more devoted bioscience technology firms are to the production of goods and services the less intellectual property-intensive they appear to be. As shown by the $\mathrm{T}$ ratios and $\mathrm{P}$ values in Figures 8 and 9, these results are statistically significant for the two most important categories of intellectual property for entrepreneurial technology firms-patents and trade secrets - regardless of how production intensity is measured.

In summary, Figures 8 and 9 indicate that variations in the commitment of firms to the production of goods and services, whether measured by human activity or financial spending, are associated with variations in the levels of the intellectual property protection for their technology. Corporate goals matter.

\subsection{Technological influences on the intellectual property profile of an enterprise}

The potential relationship between the characteristics of a firm's technology and its intellectual property profile will now be examined. As indicators of the characteristics of a firm's technology, both its "high technology" orientation (i.e., the R\&D intensity of its technology) and the technological complexity of its products and services will be 
considered. As a measure of the R\&D intensity of a firms' technology the percentage of total full-time-equivalent (FTE) employment devoted to research and development activities was obtained for each firm in the study sample. Whether or not each firm in the study sample was engaged simultaneously in multiple fields of technology, as defined in Figure 2 (specifically, biotechnology, pharmaceuticals, medical devices or bio-systems technology), is used here as a measure of the technological complexity of that firm's products and services. The diversity of a firm's technological undertakings, then, is taken here as a proxy for the complexity of that firm's technology.

\subsubsection{High technology level}

The mean level of R\&D intensity for firms in the study sample was calculated and then each firm was classified as having either above-average levels of R\&D intensity or below-average levels of $R \& D$ intensity. The intellectual property profiles of each group were then calculated and graphed as shown in Figure Ten.

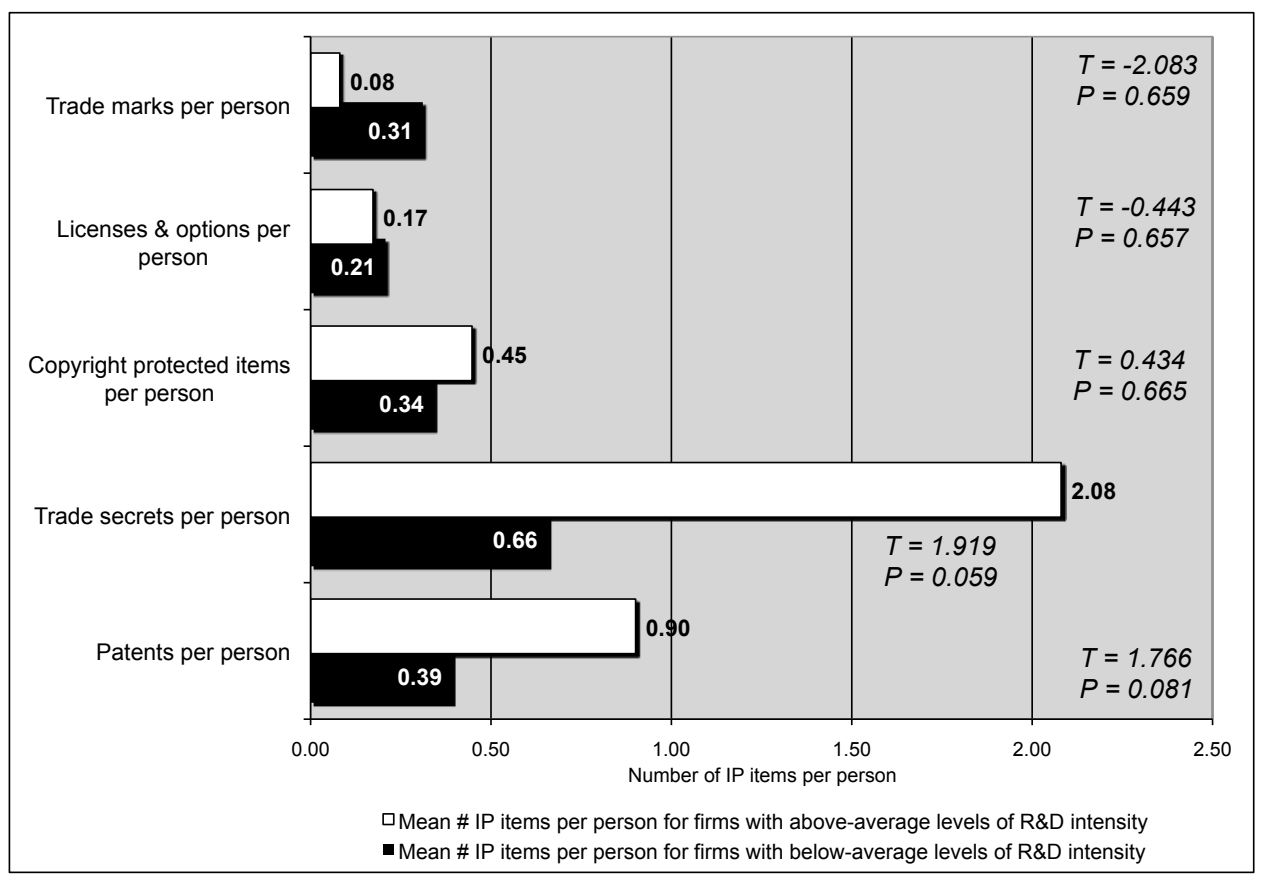

Figure 10. Relationship between R\&D intensity and the intellectual property profile of firms.

The results in Figure 10 reveal that, on the whole, firms exhibiting above-average levels of R\&D intensity are more intellectual property-intensive than those exhibiting below-average levels of R\&D intensity. This pattern is especially marked for trade secrets and patents, with trade secrets in particular standing out. Use of trade secrets to protect their technology is over three times greater (on a per-person basis) for firms with above-average levels of R\&D intensity than it is for firms with below-average levels of $R \& D$ intensity. The equivalent ratio for patent protection is significantly greater than two-to-one. As shown by the $\mathrm{T}$ ratios and $\mathrm{P}$ values in Figure 10, these results are 
statistically significant for both patents and trade secrets, which are arguably the two most important categories of intellectual property for entrepreneurial technology firms.

Trademarks are the exception here, where firms with below-average levels of R\&D intensity exhibit several times the level of use of trademarks per person than do firms with above-average levels of R\&D intensity. However, this result ought to be treated with caution, as the difference between the means is not statistically significant. There does not appear to be any significant difference between the in-licensing behavior of firms according to which group they belong.

\subsubsection{Technological complexity}

The potential impact of a firm's level of technological complexity on its intellectual property profile will now be considered. The intellectual property profile was calculated for both the group of firms with high technological complexity and the group of firms with low technological complexity. The results were then graphed as shown in Figure Eleven.

The results reveal that the level of technological complexity-at least as measured in this study - appears to have only a marginal, and statistically insignificant, effect on the propensity of firms to obtain either trade secret protection or patent protection. It also has no significant observable effect on the propensity of firms to make use of trademarks (measured on a per-person basis).

The exception to this overall result lies with copyright and licenses. The firms with above-average levels of technological complexity own almost twice as many copyright protected items per person than the firms with below-average levels of technological complexity. We can only speculate here as to the reasons for this result; and our conclusions ought to be tempered by the relatively low probability of statistical significance. Nevertheless, a plausible explanation would appear to be that the greater the complexity of a firm's technology the heavier its reliance upon software technology becomes; and, hence, the heavier its use of copyright protection for software, in its various guises, becomes. Firms with high levels of technological complexity also tend to license in the technology of other firms more heavily than those with lower levels of technological complexity. Presumably this is because the complexity of their technical repertoires generates a degree of reliance upon external sources to fill technological gaps in their systems and products. Technological complexity, we may conclude, does have an effect on the intellectual property profiles of firms, but only to a limited extent related to the protection of computer software and the licensing in of others' technology.

In summary, Figure 10 indicates that variations in the R\&D intensity of a firm's activities (i.e., the "high technology" level of a firm) are associated with variations in the profiles and levels of the intellectual property protection for their technology. Additionally, as shown by the results in Figure 11, variations in the complexity of technology between firms (namely, the diversity of their technological repertoires) also affects their intellectual property profiles. This relationship, however, is notable only for copyright and licensing behavior. Technological complexity appears to have some influence, albeit limited and irregular, on the intellectual property character of a firm. The character of a firm's technology, especially the level of R\&D input to the technology, and to some degree also its complexity, is important. Technology matters. 
Figure 11. Relationship between technological complexity (diversity) and the intellectual property

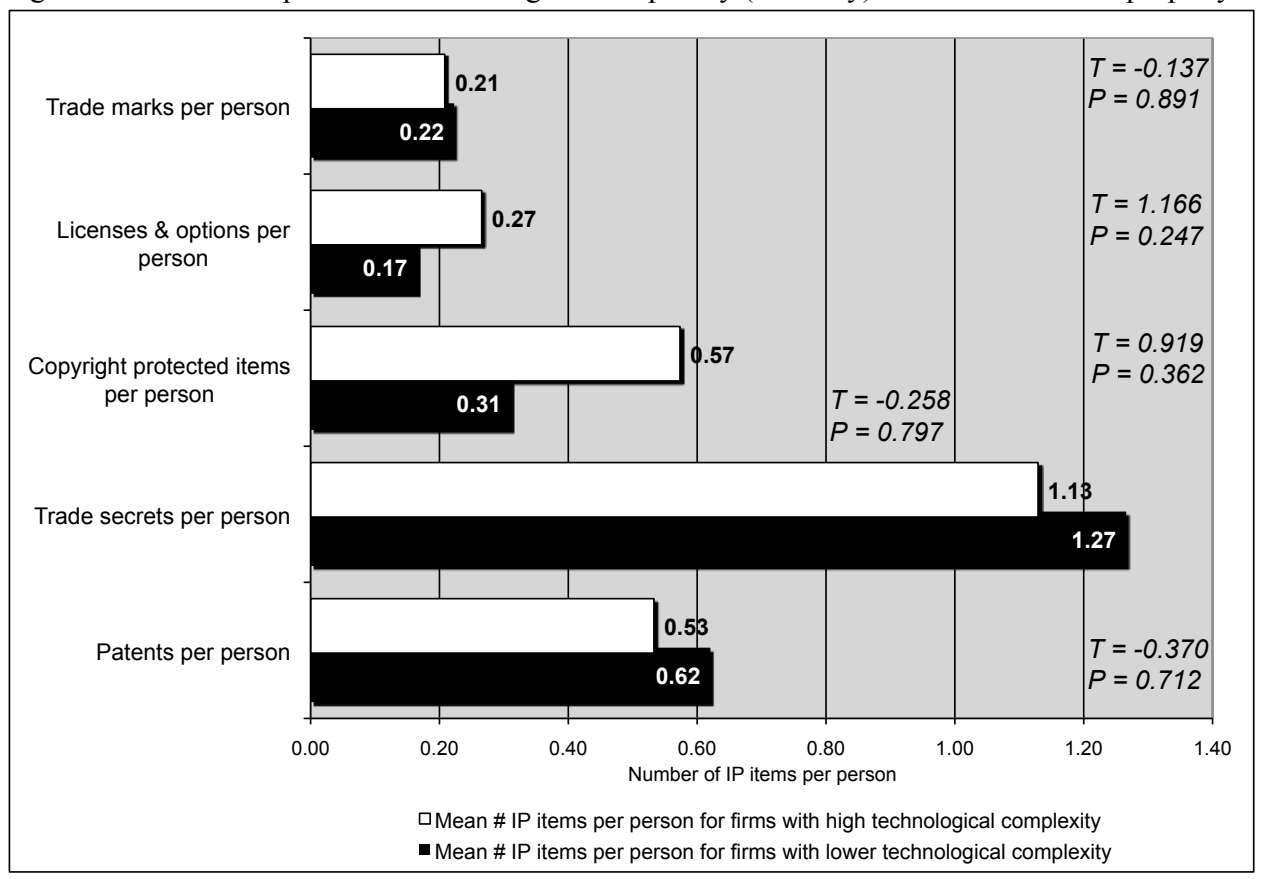

profile of firms.

\section{Conclusions and Implications}

\subsection{Main conclusions from the empirical research}

The first major conclusion to be drawn from the empirical results reported in this paper is that intellectual property plays a very prominent role in the work and business of small, young and entrepreneurial technology firms - at least those in the bioscience technology industries. The time devoted to managing intellectual property, of both managers and employees more generally, is greater for the small firms and young firms (i.e., the firms typically labeled as "SMEs"), than it is for the large mature firms. Furthermore, in contrast to the perspective adopted in much of the literature-wherein intellectual property protection is seen as the preserve of large firms, while non-legal and non-formal protection methods such as first mover advantage or stealth are seen as the natural preserve of small firms - this study has shown that small technology firms actually make greater use of formal intellectual property rights than do large firms (when the data are standardized objectively on a per-person basis).

The second major conclusion to be drawn here is that technology firms - at least technology firms in the bio-related industries - tend to follow an intellectual property portfolio management approach rather than a conventional patent administration approach. Firms of all sizes and types tend to balance and configure the use of all forms of intellectual property protection, including patents, trade secrets, copyright and trademarks, together with the judicious holding of licenses for externally sourced 
technology. The management of intellectual property portfolios appears to be a signal aspect of the strategic management of entrepreneurial technology firms.

The third major conclusion to be drawn here is that there is considerable diversity in the intellectual property profile of technology firms. The managers of technology firms appear to be constrained in their decision making by a number of forces and factorsespecially if their firms are internationally active (which almost all of them are) - that make their job of designing an appropriate intellectual property strategy rather difficult. There does not appear to be any obvious "one best way" or simple strategic formula for configuring a firm's intellectual property portfolio.

The fourth major conclusion to be drawn here is that trade secret protection, rather than patent protection, more often than not occupies the primary position in the intellectual property portfolios of firms. This heavy reliance upon trade secret protection is observable as part of the strategies of all categories of firms, including large established firms; but it is especially noticeable in the strategies of small firms, young firms and entrepreneurial firms more generally.

The final major conclusion is that the mix of intellectual property instruments adopted by firms for the protection of their technology appears to be influenced by the context, organizational-profile and goals of the technology enterprise, together with the characteristics of the pertinent technology.

\subsection{Implications for theory}

The core theme expressed by the majority of sources in the literature surveyed in the early part of this paper - that intellectual property and the management of intellectual property have great importance for both economic development and the strategic management of business enterprises - is affirmed by the research reported here. The secondary theme in the literature- that intellectual property has special implications for the business of entrepreneurial technology firms and small and medium sized enterprises (SMEs) more generally — is also affirmed by the research reported here. However, calling these insights "theoretical" insights may be a little presumptuous. At this stage we should probably say that the literature is mostly descriptive and investigative rather than truly theoretical in nature. The main implication of this research for theory, therefore, is that the time has probably come for some kind of formal theory to be developed in intellectual property management research.

Nevertheless, notwithstanding the caveat that the research here mostly takes the form of practice-oriented investigations in search of theory, some promising suggestions for the future challenge of theory development are contained in the results summarized in this paper. Evidence is provided here that there are at least four sets of factors involved in the configuration of a technology firm's intellectual property profile: (1) organizational context, (2) organizational profile, (3) corporate goals, and (4) the characteristics of the organization's technology. How might these factors be organized conceptually and elaborated within a more systematic theoretical framework? Will orthodox theories from the field of strategic management be adequate for this purpose or will some new theoryperhaps grounded in epistemology, the philosophy of technology or in the legal philosophy of property rights, for example — need to be developed? The four factors that this paper has identified as playing a role in determining the intellectual property profiles 
of technology firms will probably already be familiar to scholars of organization studies and strategic management. This suggests that, while there are no doubt some peculiar features intrinsic to the subject matter that must be included in research about intellectual property strategy, there will be utility in articulating established theory from organization studies and strategic management research for application in the general domain of intellectual property management studies.

Finally, the complexity and variety of approaches to configuring intellectual property protection for a firm's technology identified in this research raise the question of whether there is an almost infinite variety of peculiar intellectual property strategies available to firms to match the peculiar features of each individual firm's circumstances, or whether a modest number of generic strategies might be articulated between which the (probably perplexed) managers of entrepreneurial technology firms might choose?

These theoretical challenges will need to be left for future projects.

\subsection{Implications for future research}

The investigations described in this paper took place in the mode of inductive research rather than deductive research. To the extent that theory (or proto-theory) played a role, the inquiry was conducted in search of theory rather than as the application of theory. Additionally, as the situation might be described using the language of academic economics, we could say that the research results presented here are primarily positive rather than normative.

The main challenge for the next phase of research is therefore to identify normative principles that may form the basis for robust strategy prescriptions. The four sets of factors identified in this paper as being associated with the intellectual property profiles of technology firms provide clues for normative research. Could a limited set of generic intellectual property strategies be designed for entrepreneurial technology firms based upon a heuristic framework derived from systematic analysis of those four sets of factors? Doing so would be a worthwhile challenge for future research.

In addition to the challenges for normative research further positive research also remains to be conducted. There was insufficient space in this paper to systematically explore the complex relationships of the various factors associated with the intellectual property profiles of firms or to develop formal causal models of such relationships. Future research should address both of these shortcomings.

\subsection{Implications for managerial practice}

Managers of entrepreneurial technology firms are faced with the challenge of how to design an intellectual property protection portfolio for their technology as part of a wider intellectual property strategy for the firm. Building such a portfolio requires much more than assembling a set of patents across various jurisdictions. Rather, it requires artfully combining a mixture of patents, trade secrets, trademarks and copyright-among other types of legal protection - together with judicious in-licensing of externally sourced technology. One of the special managerial challenges is to locate practical decisionmaking criteria for designing the optimum configuration for the distinctive circumstances of each enterprise. 
Thus far, the academic literature does not offer managers a robust, practical and simple formula, or a standardized rubric, for making such intellectual property related decisions. However, the research results of the project summarized in this paper suggest a point of view, and a set of factors, that managers may bear in mind while approaching such decisions. This may be summarized in list form as follows:

- Organizational context matters

- the industry context matters

- the international context matters

- Organizational profile matters

- the size of the firm matters

- the entrepreneurial status of the firm matters

- the financial profile of the firm matters

- Corporate goals matter

- the level of commitment to the production of goods and services matters (the levels of both human and financial resources devoted to production matter)

- Technology matters

- the R\&D intensity (i.e., "high technology" level) of a firm's technology matters

- the complexity of a firms technological repertoire matters.

For now it would be unwise to prescribe anything precise about the relative weights or priorities of the above factors or about the sequences in which they should be considered. Rather, the research reported here suggests that a manager of a technology firm should take these factors in to account thoughtfully while artfully configuring an intellectual property portfolio appropriate for his or her firm.

Finally, the most significant conclusion of this paper is that in future research and policy making it is important to recognize that intellectual property features proportionally more prominently in the business of small entrepreneurial firms than it does in the business of large, established mature firms.

\section{References}

Ann, C. (2007). Know-how: Stiefkind des geistigen eigentums? Gewerblicher Rechtsschutz und Urheberrecht, 1: 39-43.

Ann, C. (2010). Trade secret protection vs. patent protection: Looking out for best practice (not only) in Europe. Paper presented at the 5th International Forum on Knowledge Asset Dynamics, Matera, Italy.

Ann, C., \& Grüneis, B. (2008). Herausforderung Produktpiraterie: Sind atente heute noch sinnvoll oder stärken sie nur die Piraten? Industrie Management, 24, 6: 59-62.

Ann, C., Willoughby, K. \& Bergmann, S. (2011). Strategien zur Piraterieabwehr für den Mittelstand. München: bayme vbm, Die bayerischen Metall- und Elektro-Arbeitgeber.

Anton, J. J., \& Yao, D. A. (2004). Little patents and big secrets: Managing intellectual property. RAND Journal of Economics, 35, 1: 1-22.

Apke, T. M. (2003). International protection of trade secrets when using the Internet. Management Decision, 41, 1: 43-47.

Arora, A., Fosfuri, A., \& Gambardella, A. (2001). Markets for technology: The economics of innovation and corporate strategy. Cambridge: MIT Press.

Arundel, A. (2001). The relative effectiveness of patents and secrecy for appropriation. Research Policy, 30, 4: 611-624.

Barney, J.A. (2002). A study of patent mortality rates: Using statistical survival analysis to rate and value patent assets. AIPLA Quarterly Journal, 30, 3: 317-352. 
Baudry, M., \& Dumont, B. (2006). Patent renewals as options: Improving the mechanism for weeding out lousy patents. Review of Industrial Organization, 28, 1: 41-62

Beckerman-Rodau, A. (2002). The Choice between patent protection and trade secret protection: A legal and business decision. The Journal of the Patent and Trademark Office Society, 84: 371-410.

Beckerman-Rodau, A. (2002). Trade secrets: The new risks to trade secrets posed by computerization. Rutgers Computer and Technology Law Journal, 28: 227-273.

Bessen, J. (2008). The value of U.S. patents by owner and patent characteristics. Research Policy, 37, 5: 932-945.

Bessen, J., \& Meurer, M. J. (2008). Patent failure: How judges, bureaucrats, and lawyers put innovators at risk. Princeton and Oxford, Princeton University Press.

Blind, K., Cremers, K., \& Mueller, E. (2009). The influence of strategic patenting on companies' patent portfolios. Research Policy, 38, 2: 428-436.

Blind, K., Cuntz, A., Köhler, F., \& Radauer, A. (2009). Die volkswirtschaftliche Bedeutung geistigen Eigentums und dessen Schutzes mit Fokus auf den Mittelstand - Endbericht (The economic significance of intellectual property and its protection with focus on small and medium sized enterprises - final report) (Forschungsbericht Nr. 579). Berlin, Bundesministerium für Wirtschaft und Technologie, Referat Öffentlichkeitsarbeit.

Blind, K., Edler, J., Frietsch, R., \& Schmoch, U. (2006). Motives to patent: Empirical evidence from Germany. Research Policy, 35, 5: 655-672.

Boldrin, M., \& Levine, D. K. (2008). Against intellectual monopoly. New York, Cambridge University Press.

Bontis, N. (1999). Managing organisational knowledge by diagnosing intellectual capital: Framing and advancing the state of the field. International Journal of Technology Management, 18, 58: 433-462.

Booker, L. D., Bontis, N., \& Serenko, A. (2008). The relevance of knowledge management and intellectual capital research. Knowledge and Process Management, 15, 4: 235-246.

Bosworth, D., \& Webster, E. (Eds.). (2006). The management of intellectual property. Cheltenham, UK; Northampton, MA, Edward Elgar.

Braga, C. A. P., Fink, C., \& Sepúlveda, C. P. (2000). Intellectual property rights and economic development (World Bank Discussion Paper No. 412). Washington, D.C., The World Bank.

Branstetter, L. G., Fisman, R., \& Foley, C. F. (2006). Do stronger intellectual property rights increase international technology transfer? Empirical evidence from U.S. firm-level panel data. The Quarterly Journal of Economics, February: 321-349.

Chen, Y., \& Puttitanum, T. (2005). Intellectual property rights and innovation in developing countries. Journal of Development Economics, 78: 474-493.

Cohen, W. M., Nelson, R. R., \& Walsh, J. P. (2000). Protecting their intellectual assets: Appropriability conditions and why U.S. manufacturing firms patent (or not) (Working Paper No. 7552). Cambridge, MA, The National Bureau of Economic Research.

Craig, L. \& Moore, L. (2011). Intangible assets, intellectual capital or property? It does make a difference (originally published in Front Range TechBiz, 2002), available at http://www.klminc.com/articles/frt_feb02.html (last accessed on 17 July 2011).

Curado, C., \& Bontis, N. (2006). The knowledge-based view of the firm and its theoretical precursor. International Journal of Learning and Intellectual Capital, 3, 4: 367 - 381.

Curado, C., \& Bontis, N. (2007). Managing intellectual capital: The MIC matrix. International Journal of Knowledge and Learning, 3, 2-3: 316-328.

Dolfsma, W. (2011). Patent strategizing. Journal of Intellectual Capital, 12, 2: 168-178.

Durvy, J.-N. (1999). The interface of innovation and know-how protection. Paper, European Commission, Enterprise-DG. Retrieved 18 March, 2010, from $\mathrm{ftp} / / \mathrm{ftp}$. cordis.europa.eu/pub/patinnova99/docs/keynote01_durvey.pdf

Edvinsson, L. (1997). Developing intellectual capital at Skandia. Long Range Planning, 30, 3: 366373.

Edvinsson, L. (2000). Some perspectives on intangibles and intellectual capital. Journal of Intellectual Capital, 1, 1: 12-16.

Elmslie, M., \& Portman, S. (2006). Intellectual property: The lifeblood of your company. Oxford, Chandos.

Erkal, N. (2004). On the interaction between patent policy and trade secret policy. Australian 
Economic Review, 37, 4: 427-435.

Figueroa, N., \& Serrano, C. J. (2010). Firm size, patent fit, and technology linkages: The determinants of patent trading flows in the market for technology. Unpublished manuscript, University of Toronto.

Fitzpatrick, W. M., \& DeLullo, S. A. (2005). Strategic alliances and the management of intellectual properties: The art of the contract. S.A.M. Advanced Management Journal, Summer, 38-45.

Garvey, J. M., \& Baluch, A. S. (2007). Intellectual property: Patent or padlock: Patents and trade secrets form the heart of an effective IP strategy. Retrieved 9 May 2010, 2010, from http://www.nwoinnovation.ca/article/-348.asp

Giuri, P., Mariani, M., Brusoni, S., Crespi, G., Francoz, D., Gambardella, A., et al. (2007). Inventors and invention processes in Europe: Results from the PatVal-EU survey. Research Policy, 36, 8: 1107-1127.

Goto, A., Nagata, A., Nelson, R. R., \& Walsh, J. P. (2002). R\&D spillovers, patents and the incentives to innovate in Japan and the United States. Research Policy, 31, 8-9: 1349-1367.

Granstrand, O. (2000). The economics and management of intellectual property: Towards intellectual capitalism. Cheltenham, Edward Elgar.

Granstrand, O. (Ed.). (2003). Economics, law and intellectual property: Seeking strategies for research and teaching in a developing field. Dordrecht, Kluwer Academic Publishers.

Graves, C. T., \& Range, B. D. (2006). Identification of trade secret claims in litigation: Solutions for a ubiquitous dispute. Northwestern Journal of Technology and Intellectual Property, 5(1), 68-101.

Greenberg, G. (2010). Small firms, big patents? Estimating patent value using data on start-ups' financing rounds. Paper presented at the DRUID-DIME Academy PhD Conference, Comwell Rebild Bakker, Aalborg, Denmark (21-23 January 2010).

Greenhalgh, C., \& Longland, M. (2005). Running to stand still? - The value of R\&D, patents and trademarks in innovating manufacturing firms. International Journal of the Economics of Business, 12, 3: 307-328.

Greenhalgh, C., \& Rogers, M. (2006). The value of innovation: The interaction of competition, R\&D and IP. Research Policy, 35, 4: 562-580.

Greenhalgh, C., \& Rogers, M. (2007). The value of intellectual property rights to firms and society. Oxford Review of Economic Policy, 23, 4: 541-567.

Grossman, G. M., \& Lai, E. L. C. (2005). International protection of intellectual property. American Economic Review, 94: 1635-1653.

Hanel, P. (2008). The use of intellectual property rights by manufacturing firms in Canada. Economics of Innovation and New Technology, 17, 4: 285-309.

Harabi, N. (1995). Appropriability of technical innovations an empirical analysis. Research Policy, 24, 6: 981-992.

Harhoff, D., Scherer, F.M., \& Vopel, K. (2003). Citations, family size, opposition and the value of patent rights. Research Policy, 32, 8: 1343-1363.

Häussler, C., Harhoff, D., \& Muller, E. (2009). To be financed or not ... - The role of patents for venture capital financing. Discussion Paper No. 09-003, ZEW - Centre for European Economic Research. Retrieved 3 June, 2010, from http://ssrn.com/abstract=1393725

Horstmann, I., MacDonald, G. M., \& Slivinski, A. (1985). Patents as information transfer mechanisms: To patent or (maybe) not to patent. Journal of Political Economy, 93, 5: 837.

Hussinger, K. (2006). Is silence golden? Patents versus secrecy at the firm level. Economics of Innovation \& New Technology, 15, 8: 735-752.

Jaffe, A. B., \& Lerner, J. (2004). Innovation and its discontents: How our broken patent system is endangering innovation and progress, and what to do about it. Princeton: Princeton University Press.

Jensen, P. H., \& Webster, E. (2006). Firm size and the use of intellectual property rights. Economic Record, 82, 256: 44-55.

Jin, D. (2001). The dynamics of knowledge regimes. London and New York: Continuum.

Jolly, A., \& Philpott, J. (Eds.). (2009). The handbook of intellectual property management: Developing and protecting your company's intellectual property (2nd ed.). London \& Philadelphia, Kogan Page.

Kahn, E. (Ed.). (2007). Innovate or perish: Managing the enduring technology company in the global market. Hoboken, N.J., Wiley. 
Kaiser, L. (2010). Management of intellectual property in research and development: A search for systems from the viewpoint of research and technology organizations. International Journal of Innovation \& Technology Management, 7, 3: 263-272.

Kash, D. E., \& Kingston, W. (2001). Patents in a world of complex technologies. Science and Public Policy, 28, 1: 11-22.

Keupp, M. M., Beckenbauer, A., \& Gassmann, O. (2010). Enforcing intellectual property rights in weak appropriability regimes: The case of de facto protection strategies in China. Management International Review, 50, 1: 109-130.

Kiskis, M., \& Petrauskas, R. (2005). Lessig's implications for intellectual property law and beyond them. International Review of Law, Computers and Technology, 19, 3: 305-316.

Kitching, J., \& Blackburn, R. (1999). Intellectual property management in the small and medium enterprise (SME). Journal of Small Business and Enterprise Development, 5, 4: 327-335.

Kultti, K., Takalo, T., \& Toikka, J. (2007). Secrecy versus patenting. RAND Journal of Economics, 38, 1: 22-42.

Lai, E. L. (1998). International intellectual property rights protection and the rate of product innovation. Journal of Development Economics, 55, 133-153.

Lanjouw, J.O., \& Schankerman, M. (2004a). Patent quality and research productivity: Measuring innovation with multiple indicators. Economic Journal, 114, 495: 441-465.

Lanjouw, J. O. \& Schankerman, M. (2004b). Protecting intellectual property rights: Are small firms handicapped? The Journal of Law and Economics, 47, 1: 45-74.

Lehman, B. (1996). Intellectual property: America's competitive advantage in the 21 st century. Columbia Journal of World Business, 6, 15: 6-18.

Leiponen, A., \& Byma, J. (2009). If you cannot block, you better run: Small firms, cooperative innovation, and appropriation strategies. Research Policy, 38, 9: 1478-1488.

Lichtenthaler, U. (2009). The role of corporate technology strategy and patent portfolios in low-, medium- and high-technology firms. Research Policy, 38, 3: 559-569.

Lu, L. Y. Y. (2007). Protecting intellectual property rights: How three Taiwanese IT firms protect their IP in mainland China. Research Technology Management, March-April, 51-56.

Maskus, K. E. (2000). Intellectual property rights in the global economy. Washington, DC, Institute for International Economics.

Mondal, D., \& Gupta, M. R. (2006). Innovation, imitation and intellectual property rights: A note on Helpman's model. Journal of Economics, 87, 1: 29-53.

Nonaka, I. (1994). A dynamic theory of knowledge creation. Organization Science, 5, 1: 14-37.

Nonaka, I., \& Takeuchi, H. (1995). The knowledge-creating company. New York: Oxford University Press.

Olander, H., Hurmelinna-Laukkanen, P., \& Mähönan, J. (2009). What's small size got to do with it? Protection of intellectual assets in SMEs. International Journal of Innovation Management, 13, 3: 349-370.

Ottoz, E., \& Cugno, F. (2008). Patent-secret mix in complex product firms. American Law and Economics Review, 10, 1: 142-158.

Parchomovsky, G., \& Wagner, R. P. (2005). Patent portfolios. University of Pennsylvania Law Review, 154, 1: 1-77.

Peeters, C., \& van Pottelsberghe de la Potterie, B. (Eds.). (2006). Economic and management perspectives on intellectual property rights. Basingstoke \& New York, Palgrave Macmillan.

Pisano, G. P., \& Teece, D. J. (2007). How to capture value from innovation: Shaping intellectual property and industry architecture. California Management Review, 50, 1: 278-296.

Price Jr., G. B. (2010). "Patent versus Trade Secret Protection,” Article in Eight Installments (30 November 2009 - 22 March 2010). American Chemical Society, Patent Watch, Patent Watch Archives. Retrieved 24 March 2010, from http://portal.acs.org/portal/acs/corg/content?_nfpb $=$ true\&_pageLabel $=$ PP_SUPERARTICLE\&node_id $=839 \&$ use_sec $=$ false $\& s e c$ url_var $=$ regio $\mathrm{n} 1 \&$ uuid $=54814425-72 \mathrm{c} 4-4 \mathrm{a} 25-\mathrm{ad} 87-\mathrm{ee} 418 \mathrm{~b} 0 \mathrm{~b} 5 \mathrm{a} 88$

Quinn, J. B. (1992). Intelligent enterprise: A knowledge and service based paradigm for industry. New York: Free Press.

Rherrad, I., \& Gallaud, D. (2009). Exploring appropriation strategies: evidence from French hightech firms. International Journal of Technology Transfer and Commercialization, 8, 4: 316339.

Rose, C., Cronin, J., \& Schwartz, R. (2007). Communicating the value of your intellectual property 
to Wall Street: A properly-constructed IP story can benefit a company and its stockholders. Research Technology Management, March-April, 36-40.

Rowe, E. A. (2008). Contributory negligence, technology, and trade secrets. University of Florida Legal Studies Research Paper, Gainesville, 2008-6, 1-40.

Scherer, F. M., \& Harhoff, D. (2000). Technology policy for a world of skew-distributed outcomes. Research Policy, 29, 4-5: 559-566.

Scotchmer, S. (2006). Innovation and incentives. Cambridge, MIT Press.

Serrano, C. J. (2005). The market for intellectual property: Evidence from the transfer of patents. Unpublished manuscript, University of Minnesota, Minneapolis.

Serrano, C. J. (2010). The dynamics of the transfer and renewal of patents. RAND Journal of Economics, 41, 4: 686-708.

Shultz II, C. J., \& Nill, A. (2002). The societal conundrum of intellectual property rights: a gametheoretical approach to the equitable management and protection of IPR. European Journal of Marketing, 36, 5/6: 667-688.

Siegel, L., \& Shah, F. (2006). Corporate counsel solutions: Intellectual property management, strategies \& tactics. Newark, N.J., LexisNexis.

Snyder, D. W., \& Almeling, D. S. (2008, 26 August 2008). The identification issue in trade secret litigation. Legal Intelligencer (originally published in the National Law Journal, 26/08/2008). Retrieved 3 March 2010, 2010, from http://www.tradesecretsblog.info/2008/09/the identification issue in tr.html.

Solitander, M., \& Solitander, N. (2010). The sharing, protection and thievery of intellectual assets: The case of the Formula 1 industry. Management Decision, 48, 1: 37-57.

Stead, D. R., \& Cross, A. R. (2009). The management and security of trade secrets: An exploratory study. International Journal of Intellectual Property Management, 3, 3: 256-277.

Subramanian, A. (1991). The international economics of intellectual property right protection: A welfare-theoretic trade policy analysis. World Development, 19, 8: 945-956.

Sveiby, K. E. (1997). The new organizational wealth: Managing and measuring intangible assets. San Francisco: Berrett-Koehler.

Tan, H. P., Plowman, P., \& Hancock, P. (2008). The evolving research on intellectual capital. Journal of Intellectual Capital, 9, 4: 585-608.

Teece, D. J. (2000). Managing intellectual capital. New York: Oxford University Press.

Tietz, F., Granstrand, O., \& Herstatt, C. (2006,). Towards strategic intellectual property management - events during the development: Evidence from Biotech SMEs. Paper presented at the PICMET 2006 Proceedings, Istanbul, Turkey, 9-13 July 2006.

von Hippel, E. (1988). The sources of innovation. Oxford: Oxford University Press.

von Hippel, E. (1994). Sticky information and the locus of problem solving: Implications for innovation. Management Science, 40, 4: 429-439.

von Hippel, E. (1998). Economics of product development by users: The impact of sticky local information. Management Science, 44, 5: 629-643.

Walden, E. A. (2005). Intellectual property rights and cannibalization in information technology outsourcing contracts. MIS Quarterly, 29, 4: 699-720.

Weber, C. (2002). Knowledge transfer and the limits to profitability: An empirical study of problem-solving practices in semiconductor manufacturing and process development. IEEE Transactions on Semiconductor Manufacturing, 15, 4: 420-426.

Weber, C. (2003). Rapid learning in high velocity environments. Doctoral dissertation, Alfred P. Sloan School of Management, Massachusetts Institute of Technology, Cambridge, June 2003.

Williamson, A., Kennedy, D. M., McNaught, C., \& DeSouza, R. (2003). Issues of intellectual capital and intellectual property in educational software development teams. Australian Journal of Educational Technology, 19, 3: 339-355.

Willoughby, K. W. (1992). Biotechnology in New York: A global industry in a global community. Stony Brook, New York, State University of New York, Center for Biotechnology.

Willoughby, K. W. (2004). The Affordable Resources strategy and the Milieux Embeddedness strategy as alternative approaches to facilitating innovation in a knowledge-intensive industry. The Journal of High Technology Management Research, 15, 1: 91-121.

Willoughby, K. W. (2008). How do entrepreneurial technology firms really get financed and what difference does it make? International Journal of Innovation and Technology Management, 5, 1: 1-28. 
Willoughby, K. (2011). Minnesota's competitive position in the BioBusiness Technology industries. St. Louis Park, MN: BioBusiness Alliance of Minnesota.

World Intellectual Property Organization (1979). Berne Convention for the Protection of Literary and Artistic Works, Paris Act of July 24, 1971, as amended on September 28, 1979; Berne Convention for the Protection of Literary and Artistic Works of September 9, 1886, completed at Paris on May 4, 1896, revised at Berlin on November 13, 1908, completed at Berne on March 20, 1914, revised at Rome on June 2, 1928, at Brussels on June 26, 1948, at Stockholm on July 14, 1967, and at Paris on July 24, 1971, and amended on September 28, 1979.

World Intellectual Property Organization (1996). WIPO Copyright Treaty (WCT). Adopted in Geneva on 20 December 1996.

\section{Biography}

Professor Kelvin Willoughby is Professor of Entrepreneurship and Intellectual Property at Curtin University, in the Faculty of Science and Engineering. His research, teaching and consulting address the management of intellectual property, technology-based entrepreneurship, and strategic planning for technology-based industry development. He holds doctorates in both strategic management and technology studies, and a master of laws degree in intellectual property law. Professor Willoughby has extensive experience as an educator, researcher, consultant and program leader in the United States, Europe and Asia. Previously, he has held academic, administrative and visiting positions at the Technische Universität München; the Max-Planck-Institut für Geistiges Eigentum, Wettbewerbs- und Steuerrecht; the University of Minnesota; Mahidol University; the University of Tokyo; the State University of New York at Stony Brook; the University of Utah; the Hong Kong Polytechnic University; Westminster College; the University of Western Australia; Columbia University; and the University of California at Berkeley.

\section{Acknowledgements}

I wish to thank Prof. Katsuya Tamai and his colleagues in the Department of Intellectual Property, of the University of Tokyo, for their kindness and assistance while hosting me as a Visiting Scholar during the early stages of my research for this paper; and I wish to acknowledge the generous contribution provided by Prof. Dr. Christoph Ann, Lehrstuhl für Wirtschaftsrecht und Geistiges Eigentum, Fakultät für Wirtschaftswissenschaften, Technische Universität München, in providing me with a superb collegial environment and practical support for completing the research for this paper. Thanks are also due to Prof. Dr. Norbert Bach, Technische Universität Ilmenau, and Mr. Marious Wehner, Justus-Liebig Universität Giessen, for comments on an earlier draft of the manuscript. 